\title{
Linkage disequilibrium patterns, population structure and diversity analysis in a worldwide durum wheat collection including Argentinian genotypes
}

Pablo Federico Roncallo ${ }^{1}$, Adelina Olga Larsen², Ana Laura Achilli', Carolina Saint Pierre ${ }^{3}$, Cristian Andrés Gallo ${ }^{1}$, Susanne Dreisigacker ${ }^{3}$ and Viviana Echenique ${ }^{1 *}$

\begin{abstract}
Background: Durum wheat (Triticum turgidum L. ssp. durum Desf. Husn) is the main staple crop used to make pasta products worldwide. Under the current climate change scenarios, genetic variability within a crop plays a crucial role in the successful release of new varieties with high yields and wide crop adaptation. In this study we evaluated a durum wheat collection consisting of 197 genotypes that mainly comprised a historical set of Argentinian germplasm but also included worldwide accessions.

Results: We assessed the genetic diversity, population structure and linkage disequilibrium (LD) patterns in this collection using a $35 \mathrm{~K}$ SNP array. The level of polymorphism was considered, taking account of the frequent and rare allelic variants. A total of 1547 polymorphic SNPs was located within annotated genes. Genetic diversity in the germplasm collection increased slightly from 1915 to 2010. However, a reduction in genetic diversity using SNPs with rare allelic variants was observed after 1979. However, larger numbers of rare private alleles were observed in the 2000-2009 period, indicating that a high reservoir of rare alleles is still present among the recent germplasm in a very low frequency. The percentage of pairwise loci in LD in the durum genome was low (13.4\%) in our collection. Overall LD and the high $\left(r^{2}>0.7\right)$ or complete $\left(r^{2}=1\right)$ LD presented different patterns in the chromosomes. The LD increased over three main breeding periods (1915-1979, 1980-1999 and 2000-2020).

Conclusions: Our results suggest that breeding and selection have impacted differently on the A and B genomes, particularly on chromosome 6A and 2A. The collection was structured in five sub-populations and modern Argentinian accessions (cluster Q4) which were clearly differentiated. Our study contributes to the understanding of the complexity of Argentinian durum wheat germplasm and to derive future breeding strategies enhancing the use of genetic diversity in a more efficient and targeted way.
\end{abstract}

Keywords: Durum, Linkage disequilibrium, Population structure, SNP, Diversity, Rare alleles

\footnotetext{
* Correspondence: echeniq@criba.edu.ar

'Centro de Recursos Naturales Renovables de la Zona Semiárida (CERZOS), Departamento de Agronomía, Universidad Nacional del Sur (UNS)-CONICET, Bahía Blanca, Argentina

Full list of author information is available at the end of the article
}

C C The Author(s). 2021 Open Access This article is licensed under a Creative Commons Attribution 4.0 International License, which permits use, sharing, adaptation, distribution and reproduction in any medium or format, as long as you give appropriate credit to the original author(s) and the source, provide a link to the Creative Commons licence, and indicate if changes were made. The images or other third party material in this article are included in the article's Creative Commons licence, unless indicated otherwise in a credit line to the material. If material is not included in the article's Creative Commons licence and your intended use is not permitted by statutory regulation or exceeds the permitted use, you will need to obtain permission directly from the copyright holder. To view a copy of this licence, visit http://creativecommons.org/licenses/by/4.0/ The Creative Commons Public Domain Dedication waiver (http://creativecommons.org/publicdomain/zero/1.0/) applies to the data made available in this article, unless otherwise stated in a credit line to the data. 


\section{Background}

Durum wheat (Triticum turgidum L. ssp. durum Desf. Husn) is one of the most important food crops in the world [1] with a worldwide production of about 36 millon tons [2]. It was derived from wild Emmer wheat ( $T$. turgidum ssp. dicoccoides, $2 \mathrm{n}=4 \mathrm{X}=28, \mathrm{AABB}$ ) in a two-step domestication process that took place in the Fertile Crescent (10,000 BP) and now it is cultivated globally [3]. The main producing areas of durum wheat are in the Mediterranean Basin, North America and India, Canada and Turkey being the main producer countries of this cereal, followed by Argelia, Italy and India [4]. Historically it has been used as the main source for making different products, mainly flat and leavened bread, couscous, burghul and frekeh in the West Asia, and the North and East Africa region and to elaborate pasta in Western Europe, as well as in North America and worldwide [5]. It has been suggested that durum wheat was the first type of wheat sown in the Spanish colonies in South America in 1527 [6]. In Argentina, the widespread cultivation of durum started with the introduction of European or Asian landraces, followed by the beginning of wheat breeding during the first two decades of the XXth century. The incorporation of the semi-dwarf genes $(R h t)$ during the green revolution occurred during the 70's. The older cultivars, typically conformed by high and less productive plants, were progressively replaced before the beginning of the 80's and all the durum wheat varieties cultivated in Argentina today are semi-dwarf [7]. Argentina annually cultivates the largest durum wheat area in South America (53,480 ha in 2019/20) (http://datosestimaciones.magyp.gob.ar/) mainly in the southeast of Buenos Aires province, but also in the north-center of the country in Tucumán province and minor areas in San Luis and Córdoba. Durum wheat grains are mainly used for dry pasta production, one of the main staple foods in Argentina, with a consumption of $8.54 \mathrm{~kg}$ per capita p.a. and occupying the 7 th worldwide position of production and consumption [8].

The understanding of genetic diversity available in this crop provides breeders with important knowledge to 1) properly design future strategies in plant breeding, 2) assist in germplasm collection management, and 3) conserve diversity in the national genebanks. To evaluate the genetic diversity in durum wheat, different wheat germplasm collections have been established and genetically characterized using DNA markers by several research institutions [9-17]. Genetic diversity in modern cultivars is usually decreased due to bottleneck events during domestication [18] and strong selection in breeding $[13,19]$. However, some authors [17] have found a low or null decay in diversity from landraces to modern cultivars, although they observed an effect of breeding on the linkage disequilibrium (LD) patterns and allele's frequency. Efforts in recovering genetic diversity and to capture beneficial alleles for specific traits have been made by exploring the genetic variability available in landraces [20-24] and wild relatives [25-27].

Single Nucleotide Polymorphisms (SNPs) are the most common type of polymorphism in genomes [28]. The use of array technologies developed to capture variants in SNP markers in wheat has become a cost-effective and more efficient way to assess diverse genetic resources [29]. Several wheat SNP arrays, such as the $9 \mathrm{~K}$ or $15 \mathrm{~K}$ Infinium BeadChip [30] and the $90 \mathrm{~K}$ iSelect SNP Array [31] from Illumina (https://www.illumina.com), or the $820 \mathrm{~K}$ Wheat HD genotyping Array [32], the $35 \mathrm{~K}$ Axiom Wheat Breeder's Array [33] and the Wheat $660 \mathrm{~K}$ Array [34] from Affymetrix (www.affymetrix.com), are available and have been widely used during recent years. Furthermore, Nextgeneration sequencing (NGS) based approaches, such as Genotyping by Sequencing (GBS) [35], or DArtSeq [36], and other emerging technologies are powerful tools for SNP discovery. The sequencing of hexaploid (bread) and tetraploid (wild emmer and durum) wheat genomes [3739] has anchored the molecular markers to their physical positions.

The study of LD can be defined as the nonrandom association of alleles at different loci due to genetic linkage, as well as artificial selection, drift, bottlenecks and other genetic forces [40]. Previous studies have addressed this issue in durum wheat [10, 41-43]. However, the analysis of LD patterns in a germplasm collection including Argentinian durum wheat by using an SNP array has not yet been performed. The study of LD could help to understand the effect of selection pressure exerted over the national germplasm that occurred during the breeding processes. An initial genetic characterization of a subset of the durum wheat collection used in this study was performed with AFLP and a low number of KASP $^{\text {тм }}$ SNPs markers [14]. For the present study our goals were to i) assess the genetic diversity in a collection of 197 durum wheat accessions ii) study the population structure in our germplasm collection to establish the main genetic relationships between the Argentinian durum wheat and other foreign germplasm, iii) estimate LD patterns considering the variation in the genome, population structure and the time of release of evaluated genotypes.

\section{Results}

Distribution and physical location of polymorphic SNPs From all the SNP results, 7431 SNPs were high-quality polymorphic in the 197 durum wheat accessions (Additional file 1: Table S1a, b), of which 4854 (65.3\%) SNPs showed and minor allele frequency $(\mathrm{MAF})>0.05$, hereafter called high frequency (HF) SNPs and 2577 (34.7\%) corresponded to 'rare alleles' SNP with an MAF < 
0.05, subsequently called low frequency (LF) SNPs. A total of 7222 out of 7431 polymorphic SNPs could be aligned to the Svevo whole genome sequence assembly with an average inter-marker distance of $1.38 \mathrm{Mb}$, whereas the HF and LF SNPs showed average values of $2.1 \mathrm{Mb}$ and $4.0 \mathrm{Mb}$, respectively. The SNP distribution in the durum wheat genome is shown in Table 1. The number of SNPs per chromosome ranged from 231 (4A) to 542 (1B) for HF SNPs whereas the LF SNPs varied from 70 (4B) to 337 (1B). The HF SNPs were better distributed than the LF SNPs. The $B$ genome had a higher number of polymorphic SNPs, where $1 \mathrm{~B}, 2 \mathrm{~B}$ and $6 \mathrm{~B}$ chromosomes showed higher representation. The annotation's ID and function of genes containing SNPs were listed in Additional file 2: Tables S2a, b. A total of 1547 polymorphic SNPs was located within the annotated genes, out of which 595 corresponded to LF SNPs and 952 to HF SNPs. Out of these, 16 annotated genes carried three or more than three SNP markers, and in particular, two annotations (TRITD6Bv1G225150 and TRITD7Av1G001490) showed nine and six polymorphic SNPs, respectively (Additional file 2: Tables S2c, d).

\section{Genetic diversity analysis}

Genetic diversity was analyzed in all the chromosomes considering HF and LF SNPs separately. Nei's gene diversity $(\mathrm{He}$ ) considering HF SNPs was higher for the $\mathrm{B}$ genome, showing maximum values on the $3 \mathrm{~B}$ and $1 \mathrm{~B}$ chromosomes, while the A genome showed higher values of $\mathrm{He}$ for LF SNPs (rare allele) (Table 1). When the geographical origin or period of release were taken into account the private alleles (alleles that are found only in a single subgroup) were not observed among the HF SNPs (Table 2). However, the analysis of rare alleles detected 1102 and 1122 private alleles based on geographical origin and the period of the genotype's breeding or release, respectively.

The highest genetic diversity indices ( $\mathrm{I}, \mathrm{He}, \mathrm{Ho}, \mathrm{Na}$, $\% \mathrm{PL})$ calculated using HF SNPs were observed in the modern Argentinian accessions (ARM), followed by the French (FRA) and traditional Italian ones (ITT), whereas the lowest indices were observed in the genotypes from the USA, CIMMYT and Chile (Additional file 3: Figure $\mathrm{S} 1 \mathrm{a}, \mathrm{b})$. However, when the indices and the number of private alleles (PA) were based on LF SNPs, the ITT constituted the most diverse subgroup. All 17 ITT accessions carried rare PAs and 416 LF SNP variants that were exclusive of this subgroup (37.7\% of total) giving an average of 24.5 PA by accessions (Additional file 4: Table S3a). The Chilean (303 PA) and modern Argentinian (200 PA) subgroups also captured a high number of rare SNP variants. The PCoA via distance matrix with data standardization of the Nei genetic distance evidenced that modern Argentinian genotypes are genetically related to WANA region accessions. On the other hand, Chilean accessions were closely related to CIMMYT germplasm (Additional file 5: Table S4a).

Diversity indices calculated according to the period of the genotype's breeding or release were also analyzed. The indices that were estimated using HF SNPs showed a slight upward trend between 1970 and 2009, followed by a slight reduction in diversity during the last period (2010-2020). However, the analysis of LF SNPs showed a different pattern, increasing from 1915 to1979, followed by a three-fold downward trend in diversity to the present (Additional file 3: Figure S1c,d). Despite this, the highest number of LF PAs was observed between 2000 and 2009, with 590 PA (52.6\%) followed by 396 PA in 1970-1979 (35.3\%) (Table 2). The highest average number of PAs by accession was found in the period 1970-1979 (28.3 PA). The estimated Nei genetic distance among breeding periods showed the highest differentiation between the 1960-1969 and 2010-2020 periods (Additional file 5: Table S4b).

Only 15 genotypes of the collection captured most of the rare allelic variants, in particular the cultivar Polesine (ITT, 1970-1979) and the Chilean breeding line Quc 3506-2009 (2000-2009) that carried more than 200 PA (Additional file 4: Table S3c).

\section{Linkage disequilibrium patterns}

Analysis of genome-wide LD in the whole collection showed that $13.37 \%$ of the total marker pairs had a significant LD $(p<0.01)$, with a mean $r^{2}$ value of 0.0895 . Only 4.74 and $0.95 \%$ of the significant marker pairs showed $r^{2}$ values above 0.2 and 0.7 , respectively, indicating a low level of LD in the genome. Differences in the significant intra-chromosomal LD were observed between the $\mathrm{A}$ and $\mathrm{B}$ genomes resulting in higher values in the A genome. Analysis of variance detected significant differences $(p<0.001)$ in LD between chromosomes, with the 6A chromosome having the highest mean $r^{2}$ value $\left(r^{2}=0.290\right)$, followed by $2 \mathrm{~A}, 4 \mathrm{~B}, 1 \mathrm{~A}, 4 \mathrm{~A}$ and $7 \mathrm{~A}$. Moreover, the 6A had the lower proportion of significant marker pairs in LD (15.1\%), whereas the highest value was observed in the $1 \mathrm{~B}$ chromosome (27\%) (Table $1)$. The frequency of $r^{2}$ values in each chromosome is shown in Fig. 1d.

The distribution and extent of LD were displayed as decay plots and a second-degree locally-weighted polynomial regression (LOESS) curve was fitted by chromosome, each genome and for the whole genome (Fig. 1a, b). The critical threshold $r^{2}$ value, corresponding to the 95th percentile of the distribution of the square root transformed inter-chromosomal LD, was $r^{2}=0.196$, very close to the 0.2 suggested by [44]. The intrachromosomal LD decay, below an $r^{2}$ critical threshold lower than 0.2 , showed a mean value of $11.8 \mathrm{Mb}$ in the 


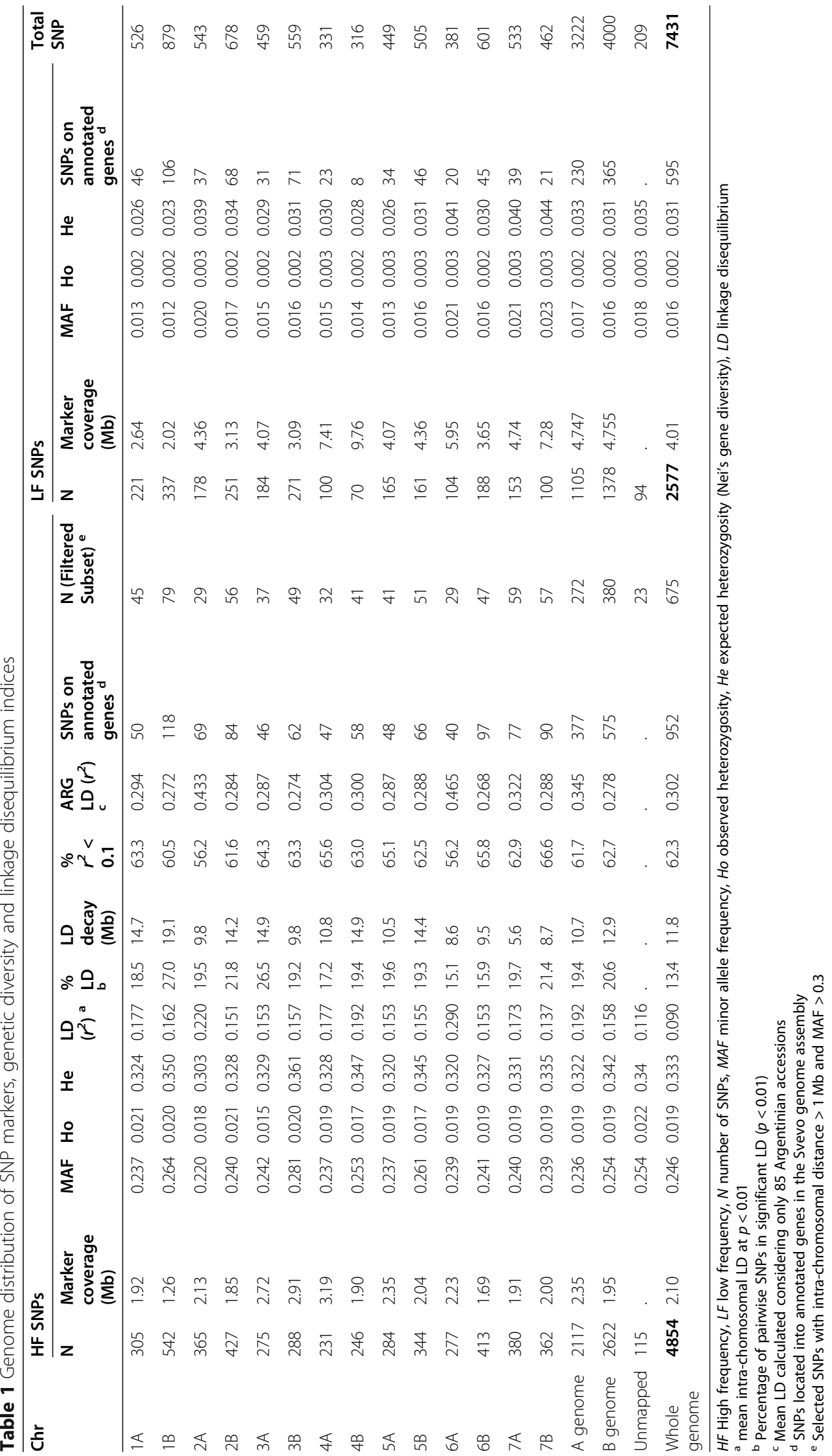


Table 2 Genetic diversity estimated in the whole collection and subgroups

\begin{tabular}{|c|c|c|c|c|c|c|c|c|c|c|c|c|c|}
\hline \multirow[t]{2}{*}{ Subgroup } & \multirow[t]{2}{*}{$\mathrm{N}$} & \multicolumn{6}{|c|}{4854 HF SNPs } & \multicolumn{6}{|c|}{2577 LF SNPs } \\
\hline & & $\% \mathrm{PL}$ & $\mathrm{Na}$ & $I$ & Ho & $\mathrm{He}$ & PA & $\% \mathrm{PL}$ & $\mathrm{Na}$ & $I$ & Ho & $\mathrm{He}$ & PA \\
\hline \multicolumn{14}{|l|}{ Origin $^{a}$} \\
\hline ARM & 71 & 98.0 & 1.98 & 0.478 & 0.029 & 0.315 & 0 & 45.4 & 1.45 & 0.051 & 0.003 & 0.022 & 200 \\
\hline ART & 14 & 83.8 & 1.84 & 0.416 & 0.016 & 0.273 & 0 & 19.6 & 1.20 & 0.056 & 0.002 & 0.031 & 50 \\
\hline $\mathrm{CHI}$ & 26 & 80.6 & 1.81 & 0.390 & 0.008 & 0.257 & 0 & 27.7 & 1.28 & 0.057 & 0.001 & 0.028 & 303 \\
\hline CIM & 10 & 66.3 & 1.66 & 0.348 & 0.003 & 0.231 & 0 & 9.1 & 1.09 & 0.032 & 0.001 & 0.019 & 1 \\
\hline FRA & 22 & 92.4 & 1.92 & 0.462 & 0.024 & 0.306 & 0 & 24.6 & 1.25 & 0.061 & 0.003 & 0.032 & 86 \\
\hline ITM & 16 & 81.4 & 1.81 & 0.423 & 0.008 & 0.282 & 0 & 12.3 & 1.12 & 0.041 & 0.002 & 0.023 & 18 \\
\hline $\mathrm{ITT}$ & 17 & 91.7 & 1.92 & 0.457 & 0.020 & 0.301 & 0 & 48.3 & 1.48 & 0.131 & 0.005 & 0.070 & 416 \\
\hline USA & 4 & 53.3 & 1.53 & 0.320 & 0.016 & 0.220 & 0 & 6.8 & 1.07 & 0.039 & 0.002 & 0.026 & 29 \\
\hline WAN & 17 & 84.7 & 1.85 & 0.424 & 0.008 & 0.280 & 0 & 17.4 & 1.17 & 0.048 & 0.001 & 0.026 & 26 \\
\hline \multicolumn{14}{|l|}{ Period } \\
\hline 1915-1959 & 6 & 70.3 & 1.70 & 0.382 & 0.015 & 0.255 & 0 & 10.6 & 1.11 & 0.047 & 0.002 & 0.029 & 12 \\
\hline 1960-1969 & 5 & 61.5 & 1.62 & 0.352 & 0.018 & 0.239 & 0 & 19.6 & 1.20 & 0.098 & 0.006 & 0.064 & 33 \\
\hline 1970-1979 & 15 & 91.0 & 1.91 & 0.460 & 0.022 & 0.304 & 0 & 48.1 & 1.48 & 0.137 & 0.005 & 0.074 & 396 \\
\hline 1980-1989 & 22 & 94.9 & 1.95 & 0.474 & 0.017 & 0.314 & 0 & 23.4 & 1.23 & 0.049 & 0.002 & 0.024 & 30 \\
\hline 1990-1999 & 24 & 95.2 & 1.95 & 0.482 & 0.008 & 0.320 & 0 & 22.7 & 1.23 & 0.046 & 0.001 & 0.022 & 32 \\
\hline 2000-2009 & 101 & 99.8 & 2.00 & 0.487 & 0.015 & 0.320 & 0 & 71.1 & 1.71 & 0.067 & 0.002 & 0.028 & 590 \\
\hline $2010-2020$ & 24 & 92.5 & 1.93 & 0.459 & 0.048 & 0.303 & 0 & 19.2 & 1.19 & 0.034 & 0.003 & 0.016 & 29 \\
\hline \multicolumn{14}{|l|}{ DAPC } \\
\hline Q1 & 68 & 99.2 & 1.99 & 0.478 & 0.023 & 0.315 & 1 & 54.2 & 1.54 & 0.066 & 0.003 & 0.029 & 313 \\
\hline Q2 & 41 & 97.3 & 1.97 & 0.450 & 0.019 & 0.293 & 0 & 35.2 & 1.35 & 0.050 & 0.002 & 0.022 & 104 \\
\hline Q3 & 36 & 92.0 & 1.92 & 0.419 & 0.014 & 0.271 & 0 & 56.0 & 1.56 & 0.108 & 0.003 & 0.054 & 511 \\
\hline Q4 & 18 & 70.6 & 1.71 & 0.327 & 0.030 & 0.212 & 1 & 8.2 & 1.08 & 0.019 & 0.002 & 0.010 & 6 \\
\hline 5 & 34 & 83.2 & 1.83 & 0.364 & 0.011 & 0.234 & 0 & 31.2 & 1.31 & 0.056 & 0.001 & 0.027 & 297 \\
\hline Total & 197 & 100 & 2.00 & 0.503 & 0.019 & 0.333 & - & 100 & 2.00 & 0.078 & 0.002 & 0.031 & - \\
\hline
\end{tabular}

HF high frequency, LF low frequency, \% PL percentage of polymorphic loci, Na average number of alleles, I Shannon's Information index, Ho observed heterozygosity, He Nei's gene diversity or heterozygosity, $P A$ number of private alleles Q1 to Q5 are the sub-population inferred by DAPC

${ }^{a}$ ARM Accessions are coded as: modern Argentinian, ART traditional Argentinian, CHI Chile, CIM CIMMYT, FRA France, ITM modern Italian, ITT traditional Italian, USA United States, WAN West Asia/ North Africa region. Accessions from Argentina and Italy were divided into two groups according to the breeding period or year of release (until: 'traditional,' and after 1985: 'modern')

whole genome below which the LD is probably caused by a real physical linkage. The LD decay varied from 5.6 (7A) to 19.1 (1B) $\mathrm{Mb}$ in the chromosomes (Table 1, Fig. $1 \mathrm{a}, \mathrm{b})$. Beyond the inter-marker distance indicated as whole genome LD decay, $88.2 \%$ of the $r^{2}$ values were below 0.2 and only $4.4 \%$ were values higher than 0.5 . Alternatively, the LD decay was calculated as the variation of the mean $r^{2}$ value across distance in each chromosome [45] (Additional file 6: Figure S2a).

LD decay was also calculated considering the Argentinian germplasm only, obtaining values of $60.6 \mathrm{Mb}$ for the A genome, $34.7 \mathrm{Mb}$ for the $\mathrm{B}$ genome and a whole genome value of $30.4 \mathrm{Mb}$ which is 2.5 fold higher than the one obtained when the whole collection was considered (Additional file 6: Figure S2b, c, d). The mean $r^{2}$ values for the Argentinian germplasm and by chromosome are also shown in Table 1.

On the other hand, the number of marker pairs, in high $\left(r^{2}>0.7\right)$ or complete LD $\left(r^{2}=1\right)$, was assessed for each chromosome and its distribution considering the inter-marker distance was evaluated. As a result, the percentage of marker pairs in complete intra-chromosomic $\mathrm{LD}\left(r^{2}=1\right)$ in the whole genome was very low $(1.97 \%)$. The 2A, 6A, 1B, 2B, 7A chromosomes showed the highest number of marker pairs in complete $\mathrm{LD}$, whereas $1 \mathrm{~B}$, $2 \mathrm{~A}, 6 \mathrm{~A}, 7 \mathrm{~A}$ and $2 \mathrm{~B}$ exhibited the highest number in high LD $\left(r^{2}>0.7\right)$. This analysis was repeated taking into account only the Argentinian germplasm being the number of marker pairs in high LD $\left(r^{2}>0.7\right) 11.7 \%$ higher and the complete LD $\left(r^{2}=1\right) 88.9 \%$ higher than in the 
a

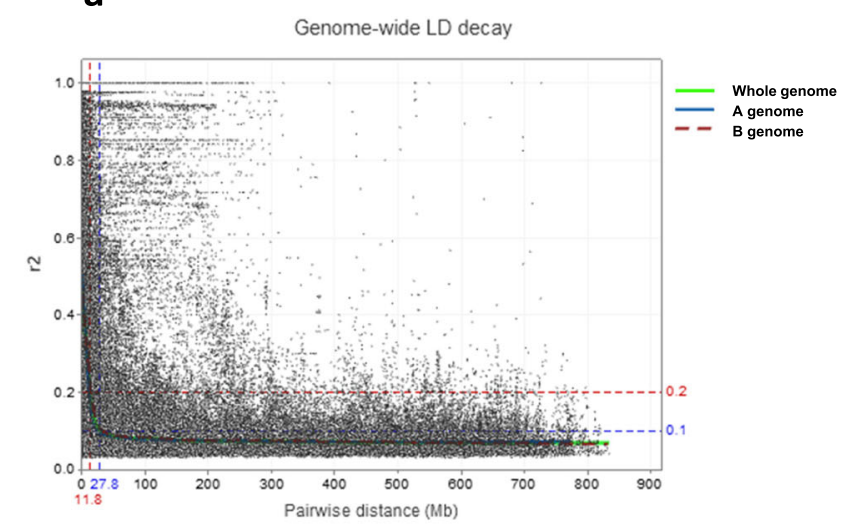

C

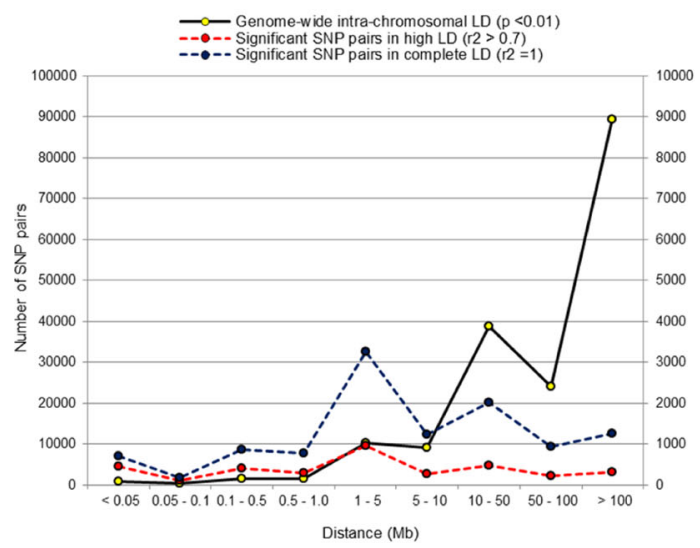

b

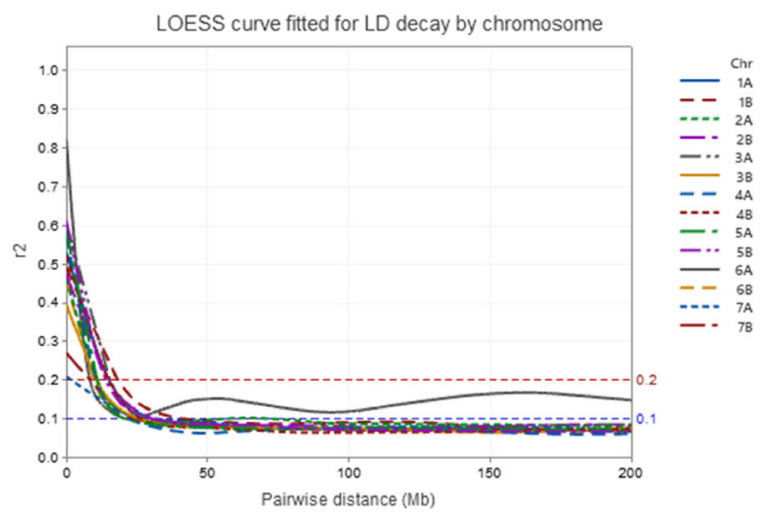

d

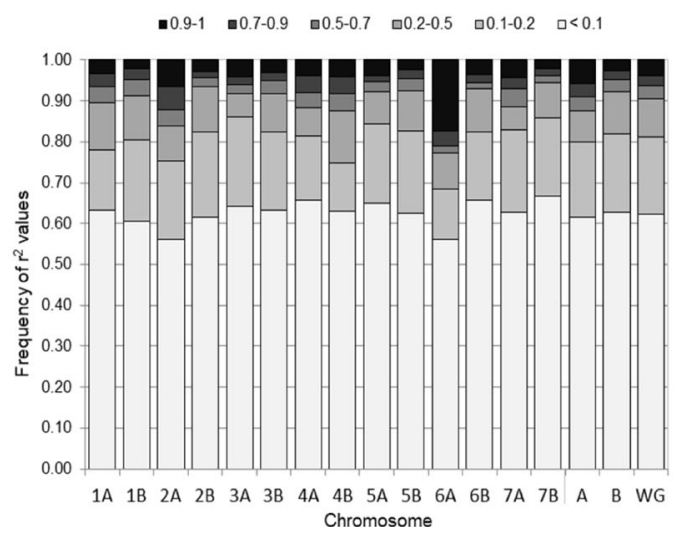

Fig. 1 Genome-wide linkage disequilibrium (LD) distribution and LD decay. a Scatter plot of LD values of intra-chromosomal pairwise loci against physical distance (Mb). LD decay was fitted with the locally weighted polynomial regression-based (LOESS) curve by genome and for genomewide LD. $\mathbf{b}$ LOESS curves fitted by chromosome (only distance to $200 \mathrm{Mb}$ is shown); c Number of SNP pairs in LD distributed along physical distance intervals; d) LD $\left(r^{2}\right)$ values frequency by chromosome, genome and whole genome

whole collection, in particular for the $6 \mathrm{~A}, 2 \mathrm{~A}, 7 \mathrm{~A}$ and $1 \mathrm{~B}$ chromosomes (Additional file 6: Figure S2e, f).

Considering the whole genome, the number of pairwise SNPs showing high $\left(r^{2}>0.7\right)$ or complete LD $\left(r^{2}=\right.$ 1) values was maximum in an inter-marker distance range of 1 to $5 \mathrm{Mb}$ (Additional file 6: Figure S2g, h). However, different behavior was observed in three chromosomes (2A, 7A and 6A) showing an increasing number as the distance between pairs of SNPs increased, suggesting a higher extension of high LD in these chromosomes. The 1B chromosome exhibited extended high LD between 1 and $50 \mathrm{Mb}$, also shown in Additional file 6: Figure S2d. LD heat maps by chromosome and for whole genome revealed larger $\mathrm{LD}$ blocks on chromosomes 6A, 4B, 2A, 7A, 4A, 1B, 1A and 3B (Additional file 7: Figure S3a, b).

In addition, the inter-marker distance estimated considering the SNP pairs in complete LD was higher in the Argentinian germplasm compared with the whole collection values (Table 3 ).
An overall increase over time in significant LD, and also in the extension of LD measured as an average of inter-marker distance (Mb) (Fig. 2), was observed as an effect of breeding, considering three main periods (1915-1979, 1980-1999 and 2000-2020). In this sense, the number of pairwise SNPs in high LD $\left(r^{2}>0.7\right)$ increased over time, but the proportion of these markers decreased as a consequence of an overall increase in the background LD. Different LD patterns in the A and B genomes and in the chromosomes were observed over time (Additional file 8: Figure S4). In general, the SNP pairs on the $\mathrm{B}$ genome in high $\mathrm{LD}$ decreased between the second and third periods. The 6A chromosome was the only one showing an increase in the number and a proportion of pairwise in complete $\mathrm{LD}=1$ simultaneously over time.

\section{Population stratification and diversity}

The population structure was studied in our collection using a subset of 675 markers selected from the 
Table 3 Mean inter-marker distance for SNP pairs in complete $\operatorname{LD}\left(r^{2}=1\right)$

\begin{tabular}{lll}
\hline Chr. / Genome & Whole collection & Argentinian accessions \\
\hline 1A & 7.38 & 6.57 \\
1B & 14.93 & 10.52 \\
2A & 69.79 & 81.28 \\
2B & 5.63 & 5.48 \\
3A & 8.07 & 14.34 \\
3B & 3.66 & 17.84 \\
4A & 6.69 & 8.68 \\
4B & 3.13 & 3.00 \\
5A & 5.56 & 10.79 \\
5B & 0.91 & 2.04 \\
6A & 29.50 & 57.48 \\
6B & 9.07 & 19.84 \\
7A & 41.40 & 51.93 \\
7B & 23.95 & 30.72 \\
A genome & 35.13 & 53.96 \\
B genome & 7.46 & 13.11 \\
Whole genome & 25.12 & 37.79 \\
\hline
\end{tabular}

Chr. chromosome

complete dataset. These markers were almost evenly distributed throughout the whole genome (Table 1).

Five sub-populations were inferred by the Discriminant Analysis of Principal Components (DAPC) based on BIC criterion (Fig. 3). For this analysis, 40 PCs were retained using the cross-validation method. The modern Argentinian germplasm was mainly distributed in four sub-populations, Q1 (28), Q2 (16), Q4 (16) and Q5 (9), indicating the high diversity present in this germplasm. The only modern Argentinian cultivar included in Q3 was BonINTA Cumenay. Three traditional Argentinian accessions were included in Q1, one in Q2, nine in Q3 and only one in Q4.

The sub-population Q1 mostly included modern Argentinian accessions (28), most of the French germplasm (19 out of 22) and intermediate contributions of WANA (6), Chile (4), traditional Argentinian (3) and modern Italian accessions (3). Two out of the three Argentinian breeding programs included in this study (INTA and ACA) made a major contribution to this group and $72 \%$ of the germplasm included in Q1 corresponded to the last two breeding decades. Among these contributions the Argentinian cultivar BonINTA Carilo was widely present in the pedigree of the breeding lines of this subpopulation. The U.S. cultivar Kofa was also included in this group, as well as several breeding lines from the Argentinian program of ACA which frequently used Kofa as a parental line for end-use quality traits.
The sub-population Q2 included 16 Argentinian accessions, followed by nine from WANA, five from Chile, three from CIMMYT and three modern Italian genotypes. This sub-population showed greater influence in the pedigrees of accessions from the CIMMYT/ICARDA breeding programs. The Q2 cluster included four Om Rabi accessions and its parental line Haurani, all from the WANA region. The founder genotypes Altar 84 (Gallareta) and Yavaros-79 (Chagual INIA), two genotypes widely used by CIMMYT in different breeding programs, were also included. The cultivar Buck Topacio (PROB611/Altar 84) belongs to this sub-population, cultivated in Argentina for 20 years, together with derivative breeding lines from INTA and BUCK Semillas.

The sub-population Q3 was mainly composed of Italian germplasm (24 of 36), i.e. 15 out of 17 traditional, and nine modern, Italian accessions. This subpopulation also includes nine out of the 14 traditional Argentinian accessions and it is mostly composed of old genotypes (58\%), released between 1915 and 1979, with great influence of Cappelli and Taganrog, two founder genotypes. The only modern Argentinian genotype included in Q3 (BonINTA Cumenay) is mainly a derivative of the last two mentioned genotypes. In addition, here were included all the accessions from the Gerardo group (GIORGIO//CAPELLI/YUMA).

The fourth subpopulation (Q4) was the smallest group (18) inferred by DAPC, mostly corresponding to 16 modern and one traditional Argentinian (Buck Candisur, from 1982) and one French accessions (Arcodur). This cluster mainly included germplasm from the BUCK breeding program, or breeding lines from INTA, but carrying a genetic derivative from BUCK Semillas. Eighty three percent $(83 \%)$ of the germplasm included in Q4 was developed in the last 20 years. In addition, the pedigree analysis showed a wide use of the cultivar Buck Ambar as part of these crosses.

Pedigree analysis showed that the sub-population Q5 included accessions with the greatest influence of CIMM YT germplasm, mainly bred or released during the 2000-2020 period. This group includes most of the Chilean breeding lines (17) and two recently released cultivars, Lleuque INIA (2011) and Queule INIA (2014). This group was also composed of 10 Argentinian accessions and germplasm from CIMMYT nurseries (6).

Population structure was also studied using the Bayesian model-based method implemented in STRUCTURE software. In contrast to DAPC, this analysis obtained a maximum $\Delta \mathrm{K}$ at $\mathrm{K}=2$, indicating less ability to discriminate the sub-populations clearly. At $\mathrm{K}=2$ the sub-population Q1_K2 with 85 accessions was mainly composed of germplasm with the greatest CIMMYT contribution, including 30 modern Argentinian genotypes, all the Chilean accessions (26), 10 CIMMYT cultivars or breeding lines, and 

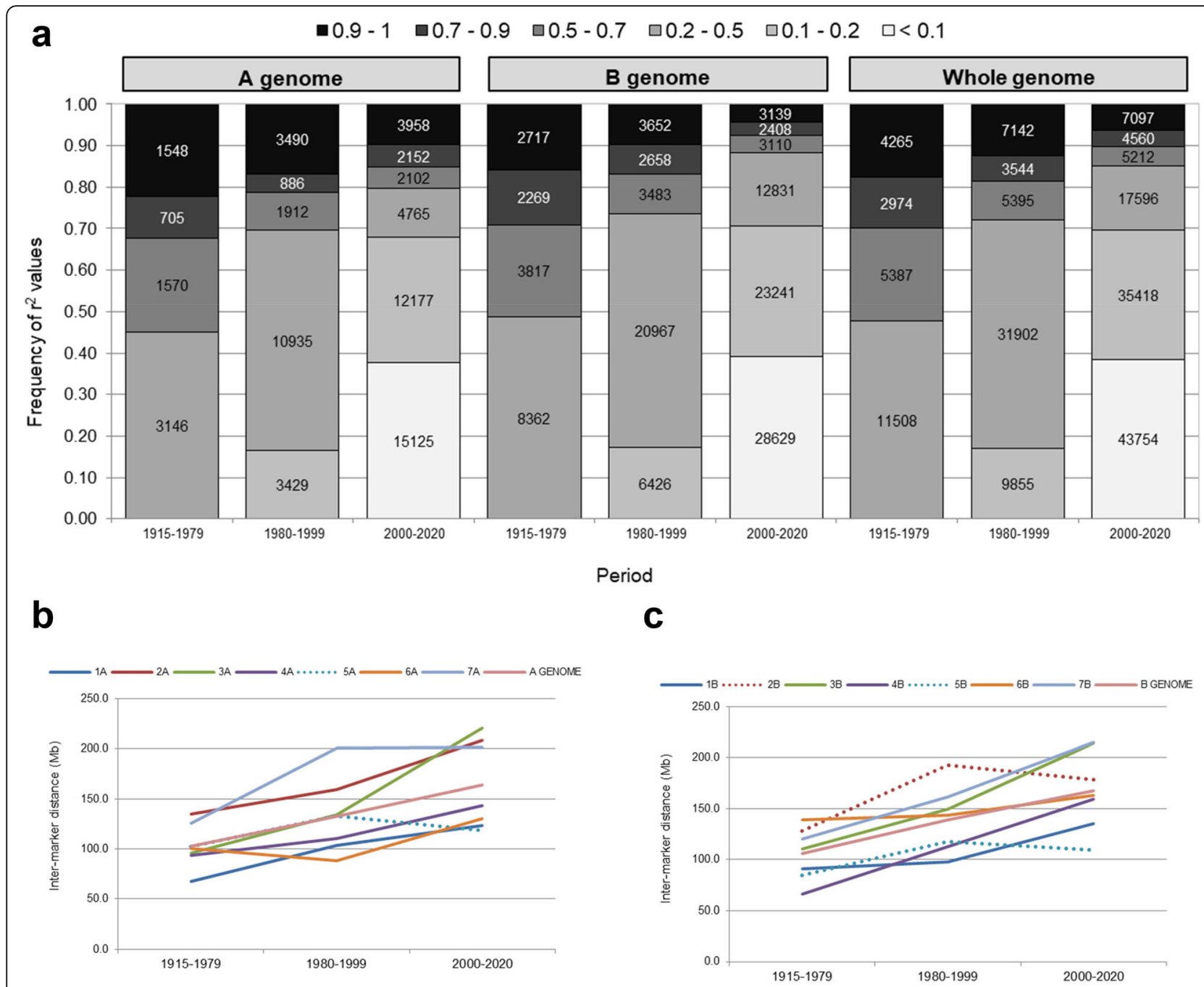

Fig. 2 Comparison of LD distribution in three breeding periods (a). Changes of average inter-marker distance in significant $L D(p<0.01)$ over time assessed by chromosome (b) and genome (c)

half (9) of the WANA region accessions. On the other hand, the sub-population Q2_K2, consisting of 112 genotypes, included 41 modern and 12 traditional Argentinian accessions and most of the Italian, French, American and half of the WANA region accessions (detailed in Additional file 9: Table S5a). Population stratification was tested by the genetic distance-based method, followed by a Ward hierarchical clustering implemented in the DARWIN v6.0 software (Fig. 4). This analysis was able to establish the genetic relationships between accessions and also to detect the main sub-populations previously identified using DAPC. Based on pedigree information, sister lines (such as Buck 44, Buck 45 and Buck 46) and breeding lines with their parental lines were clustered together, as for example BonINTA Carilo and their derivatives.

The number of sub-populations defined a priori by DAPC $(K=5)$ and the two additional methods were compared. The Ward clustering method divided Q2 (DAPC) into two main blocks, Q2a more closely related to Q1 and Q2b clustered proximal to Q5. Q2b represented genotypes with major influence of CIMMYT, including the founder genotypes Altar-84 and Yavaros-79. When the convergence of these three methods was analyzed a clear pattern in the assignment of accessions to Q3, Q4 and Q5 was observed, showing several differences between Q2 from DAPC and Ward clustering and between Q1 from DAPC and STRUCTURE (detailed in Additional file 9: Table S5b). The results of a comparison between the Ward clustering method and STRUCTURE are graphically displayed in Additional file 10: Figure S5.

The Analysis of Molecular Variance (AMOVA) considering the five DAPC genetic sub-populations revealed that $22 \%$ of the variation $(p<0.001)$ was between subpopulations and $78 \%$ was intrapopulation. In addition, 


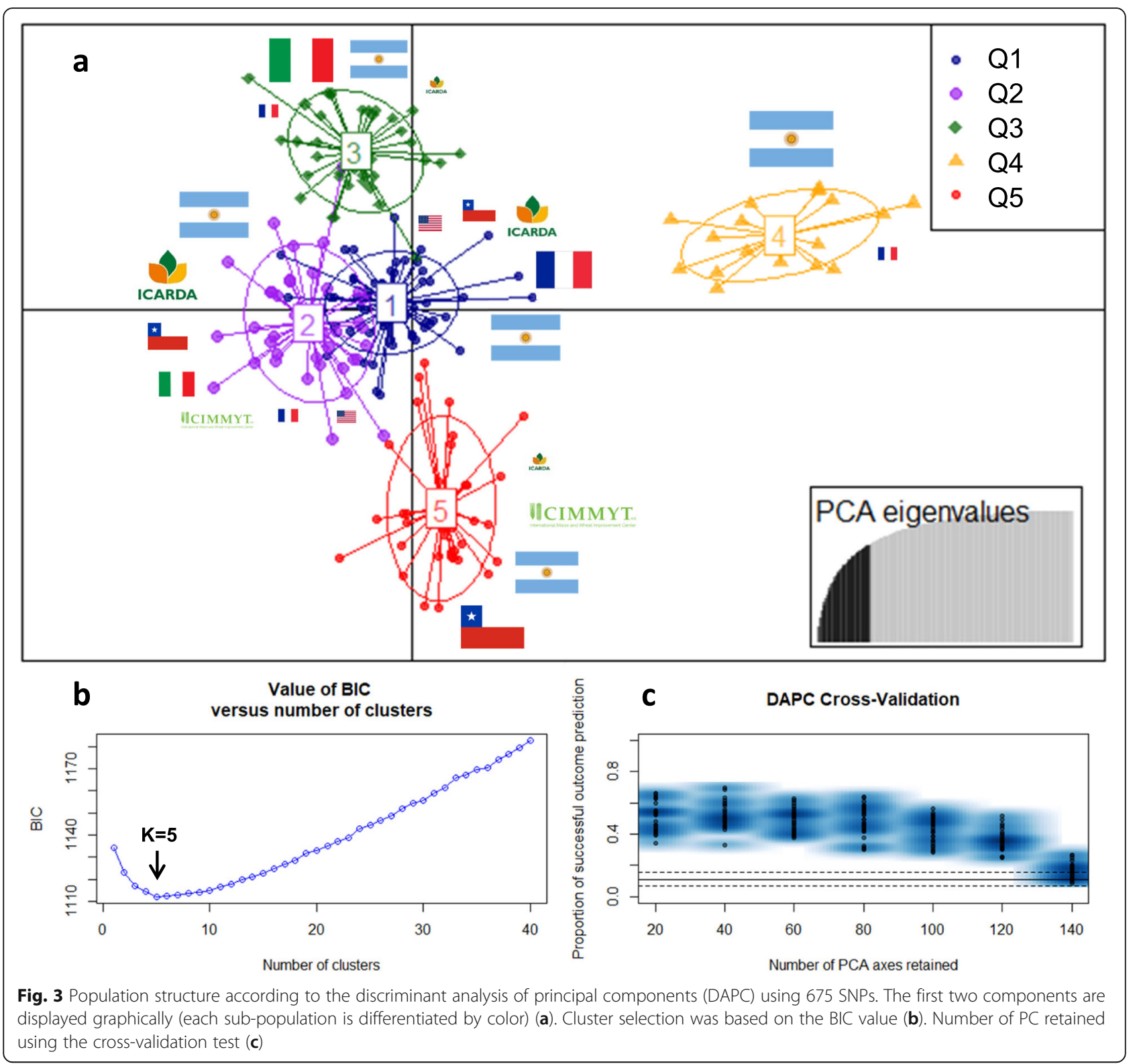

the pairwise Fst index showed that the Q5 (CIMMYT derivatives) and Q3 (mostly Italian germplasm or derivatives) ( Fst $=0.337)$ sub-populations showed the most difference. Q4 with Q3 and Q4 with Q5 also exhibited high pairwise $F s t$ and $H e$ values, but lower than the former mentioned pair of sub-populations. (see Additional file 5: Table S4c).

The Q1 sub-population from DAPC showed the highest Nei's gene diversity index $(\mathrm{He})$, followed by Q2 and Q3. Using HF SNPs only two private alleles were detected, one in Q1 and another in Q4. Considering the LF SNPs, also called rare alleles, the highest diversity (as $H e$ and $I$ index) and number of private alleles were observed in Q3, followed by Q1 and Q5.

\section{Discussion}

Distribution and physical location of polymorphic SNPs

In this study a total of 7431 polymorphic SNPs were assessed in the 14 durum wheat chromosomes using a collection of 197 accessions, facilitated by the availability of high quality genome assemblies that allowed the colocalization of markers [37-39]. SNP loci in annotated genes (Svevo genome assembly) were verified, considering both the LF SNPs and the HF SNPs. In both cases, SNPs were found in the annotated genes, representing $20.8 \%$ of the total polymorphic SNPs $(23.1 \%$ LF and $19.6 \%$ HF SNPs). In most cases only one SNP was located on a gene (80\% of SNPs alignments). However, in some genes several polymorphic SNPs (up to nine) could 


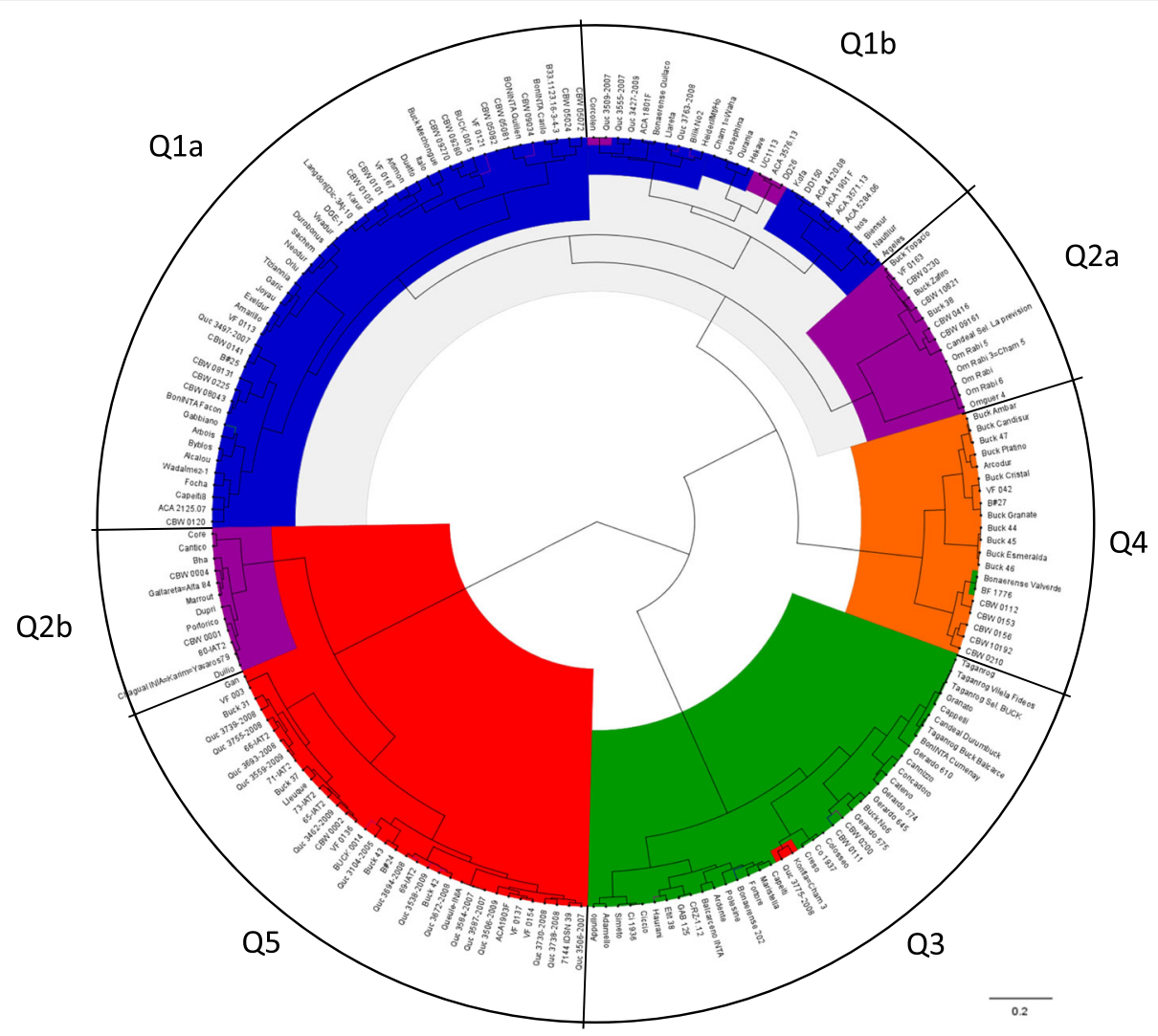

Fig. 4 Phylogenetic relationships based on genetic distance in 197 durum wheat accessions displayed graphically using a Ward dendrogram. The sub-populations found by DAPC are indicated with colors and named on the external circle

be found. According to [46], allelic rare variants could contribute to complex disease resistance and discarding them might reduce the chance to find associations with disease resistance traits. In our study 16 SNPs with rare alleles and 43 HF SNPs were found in annotated disease resistance genes (NBS-LRR domains and other). An increase in the frequency of rare alleles in breeding programs introduced from landraces or related wild species is a commonly adopted method for gaining variability $[47,48]$. The parallel identification of allelic variations for known functional genes contributes to the efficient use of genetic resources for widening genetic diversity in elite wheat lines.

Furthermore, the results showed other annotated genes carrying polymorphic SNPs aligned as the Gli-B1 locus encoding for gamma-gliadin in 1BS chromosome ([LF], AX-94659353), the HYD-B1 locus encoding the carotenoid $\beta$-hydroxylase 1 gene ([HF], AX-94475906) in the 2B chromosome, a soluble starch synthase gene (ss3) located in 1A (two LF SNPs, AX-95209651 and AX-94805209) and a lipoxygenase gene putatively encoding the $L p x-A 2$ locus in chromosome 5A ([HF], AX-94964352), all important genes associated with relevant quality traits in durum wheat breeding programs [49-52].

\section{Genetic diversity}

The genetic diversity using HF SNPs assessed in our collection was moderate $(I=0.503, \mathrm{He}=0.333)$, but acceptable considering the bi-allelic nature of the SNPs. Lower indices were reported for 259 genotypes $(I=0.38, H e=0.24)$ included in a durum wheat collection (old and modern Italian cultivars and landraces) by [17]. Also, [53] reported lower values $(H e=0.228)$ using 150 durum wheat landraces and cultivars from 1901 to 2009. Genetic diversity based on the number of low frequency SNPs was also assessed. The number of rare related alleles has been directly associated with the allelic richness in subdivided populations [54] and it is also considered as an indicator of gene flow between subpopulations [55]. Allelic richness is an alternative criterion for measuring genetic diversity and is considered a key parameter for germplasm conservation programs [56]. Loss of rare alleles could be associated with genetic erosion and decreased long-term adaptation [57]. The use of a low number of parental lines or the recurrent use of cultivars in breeding produces a narrowing of the genetic base and could be responsible for a founder effect or loss of allele richness in the segregating germplasm. This was observed in the Q4 subpopulation which exhibited the lowest percentage of polymorphism in LF SNPs. 
Based on geographical origin, the modern Argentinian genotypes exhibited the highest level of genetic diversity (He or $I$ index) followed by French and traditional Italian genotypes when HF SNPs were used. The traditional Italian genotypes exhibited the highest diversity $(\mathrm{He})$ estimated using the LF SNP and also the highest number of private alleles. The modern Argentinian accessions showed a slightly higher $\mathrm{He}$ value (for HF SNPs) and a higher number of private alleles (for LF SNPs) than the modern Italian genotypes. The decreased diversity observed using both HF and LF SNPs from traditional and modern Italian accessions agrees well with the results of [19]. Similar values of Nei and Shannon indices in the old and modern Italian cultivars were reported by [17].

Genetic diversity over a timeline (using HF SNPs) showed a slight increased (5.4\%) between the 19701979 and 2000-2009 periods but decreased during the latest one (2010-2020) returning to a similar $\mathrm{He}$ value as in the 1970-1979 period. On the contrary, [13] only considering Canadian germplasm, reported a decline in diversity from 1950 to 2010. In the same way, genetic diversity decreased during the development of the ICARDA breeding program from 1974 to 2007 [58]. Interestingly, even though a reduction in Nei's diversity index, using LF SNPs, was observed between the 1970-1979 and 2000-2009 periods, the number of LF and private alleles was higher in 20002009 than in the other periods. According to [59] the number of alleles per locus detected in a finite population depends on the effective population size. This concept could explain the high number of LF SNPs captured in the 2000-2009 period which exhibit the highest number of genotypes. It is promising to observe that allelic richness is preserved within the more recent germplasm. This period included most of the modern Argentinian, Chilean and French genotypes. A decrease in genetic diversity estimated using LF SNPs was also observed by [58], suggesting that effective strategies to incorporate and increase the amount of these variants should be addressed. Recent studies in wheat associated LF SNPS (rare alleles) with larger grains [60], or improvements in grain size and yield in rice [61]. These alleles could also be used to trace the degree of genetic contribution in different sub-populations [62] and could have long-term implications in the adaptive response towards environmental changes [57]. Otherwise, short-term response to selection is highly dependent on additive genetics estimated as expected heterozygosity $(\mathrm{He})$ [63]. Accordingly, this study provides evidence to define genetic diversity strategies in breeding programs aiming to maximize both heterozygosity and allelic richness in order to obtain a rapid short-term response to selection and producing more resilient wheats.

\section{LD patterns}

The extent and distribution of linkage disequilibrium in the genome define regions that are inherited together [64]. Our analysis detected $13.4 \%$ of the total marker pairs with significant LD $(p<0.01)$, a considerably lower percentage in comparison with the $42 \%(p<0.001)$ obtained by [15] and the intra-chromosomal LD values reported by $[48,65,66]$. In our collection, high LD $\left(r^{2}>\right.$ 0.7 ) was only represented in $0.94 \%$ of significant pairwise comparisons, being four-fold lower than the value reported by [67]. Considering a threshold of the 95th percentile of the root transformed $r^{2}$ value distribution $\left(r^{2}=0.196\right)$, the LD decay $(11.8 \mathrm{Mb})$ detected in our collection was acceptable for modern cultivars and it was similar to the values obtained in other durum wheat panels (9.6 Mb in [15] and $9.96 \mathrm{Mb}$ in [17]), but lower than the distance $(51.3 \mathrm{Mb})$ reported by [68] and by [41] (21 cM) or by [42] (14 cM). However, for breeding purposes the estimation of LD decay in local germplasm could be useful due to the differences between regional germplasm and large populations, as was observed between the Argentinian accessions and the whole collection where we could observe a 2.5 fold higher LD decay values. An increase in the mean inter-marker distance was also observed in the SNP pairs in complete LD.

According to [69], the trend in LD decay could be described using different estimators or functions. In the present study, the number of SNP pairs in high $\left(r^{2}>0.7\right)$ or complete $\operatorname{LD}\left(r^{2}=1\right)$ over distance was described, finding the highest number of significant pairs in LD between 1 and $5 \mathrm{Mb}$. A different pattern was observed when overall LD was considered. Some authors reported the presence of local epistasis in winter wheat [70], but the LD pattern could vary substantially with the population [40]. Some authors indicate that high LD between closely linked loci can be created by genetic drift, bottlenecks or selection [70]. However, some chromosomes, such as 2A and 7A, showed an extended and rising number of SNPs in high or complete LD as a function of distance, probably due a differential selection pressure exerted on these chromosomes to maintain agronomically advantageous or epistatic loci during the breeding process $[40,71]$. In the overall LD, the number of SNP pairs in significant LD became higher as the pairwise distance increased (presented in Fig. 1c). In addition, the LD patterns between neighboring loci were also analyzed by plotting heat maps and several $\mathrm{LD}$ blocks were observed on the $6 \mathrm{~A}, 1 \mathrm{~B}, 4 \mathrm{~B}, 2 \mathrm{~A}, 7 \mathrm{~A}, 1 \mathrm{~A}$ and $3 \mathrm{~B}$ chromosomes. Long-range LD blocks on $1 \mathrm{~B}$ and $6 \mathrm{~A}$ chromosomes were also reported by [72] and signatures of selection based on LD on $1 \mathrm{~B}$ and 7A were observed by [73]. Some of these regions could correspond to the putative position of major known genes in wheat, such as dwarfism genes $R h t-1$ (4B and 4A, [74]), the photoperiod 
sensitivity gene Ppd-A1 (2A, [75]), the glutenin loci Glu2/Glu-3 and Glu-1 (1B and 1A, [49, 76], the Gliadins Gli-2 and TaGW2 loci (6A, [77, 78]) or TaSus1 (7A) (https://wheat.pw.usda.gov/GG3/node/759 [39, 79];).

LD patterns assessed over three main breeding periods (1915-1979, 1980-1999 and 2000-2020) demonstrated an increased number of overall pairwise LD over time. Even though, a reduction in the mean $r^{2}$ value was observed over the three periods due to a dilution effect caused by a higher proportion of background LD $\left(r^{2}<\right.$ $0.5)$. The occurrence of high background LD was supported by an increased average inter-marker distance in most of the chromosomes over time. Chromosomal LD pattern over time suggested that breeding and selection have impacted differently on the A and B genomes. In our collection, the SNPs with high or complete LD decreased from 1980 to 1999 to 2000-2020 in the B genome, but consistently increased over time in the A genome. The highest effect of artificial selection over time was observed for the $6 \mathrm{~A}$ chromosome. Previous reports also indicated differences in $\mathrm{LD}$ patterns in the $\mathrm{A}$, $B$ and D genomes in bread wheat $[42,48,80,81]$.

\section{Population structure}

Population stratification can occur as a consequence of artificial selection in breeding, parental bottlenecks, geographical origin of germplasm and genetic drift [82-85]. Population structure using different methods was applied, as suggested by [86]. We used the Bayesian model-based method implemented in STRUCTURE, a nonparametric method, as DAPC and a distance-based clustering method (Ward).

This study evaluated 111 South-American durum wheat accessions (mainly from Argentina and Chile), including also additional world-wide genotypes. Our results indicated the existence of five sub-populations with moderate to high differentiation (Fst ranging from 0.139 to 0.337$)$, slightly higher than the one reported by [13], but lower than that of [17] which included a large collection of landraces. The AMOVA assessed considering these sub-populations explained about $22 \%$ of the variance between groups, a lower value than reported by [12]. The DAPC and Ward clustering results showed that the modern Argentinian germplasm combines contributions from different genetic sources, such as Mediterranean genotypes (Q1 and $\mathrm{Q} 2)$, or accessions from CIMMYT (Q5 and partially in Q2). An interesting result was the evidence that a part of the modern Argentinian accessions (Q4) was clearly differentiated from the remaining sub-populations, mostly germplasm from BUCK Semillas company. This finding confirms previous results obtained by our group based on 26 SNPs $\left(\mathrm{KASP}^{\mathrm{m}}\right)$ that gave indications of a possible genetic differentiation [14]. On the other hand, the STRUCTURE results were able to differentiate clearly only the $\mathrm{K}=2$ as the main stratification level, based on $\Delta \mathrm{K}$ parameter. However, considering the clustering of entries at the $\mathrm{K}=5$ level this result gave up to $77 \%$ of coincidence with DAPC (100\% in Q3 and Q4 as it is shown in Additional file 10). The use of different methodologies as suggested [86] contributed to better understanding of the genetic relationships between the accessions and lets to infer that the cluster Q4 have greater similarity with the Mediterranean germplasm.

In addition, there was evidence of a founder effect of Buck Ambar in this modern Argentinian germplasm (Q4). Whereas that another two Argentinian cultivars, BonINTA Carilo (Q1) and Buck Topacio (Q2), were widely used in crosses and their derivative lines were mostly clustered together with the parental lines. In comparison, the ACA Coop Ltda. breeding program extensively used the desert durum cultivar Kofa, which was clustered with its derivative breeding lines in Q1. Considering all the methodologies used in this study, population structure analysis also divided the traditional or old germplasm, mostly included in Q3 $(\approx 75 \%$ bred before 1989), from the modern ones. Most of the landraces (Taganrog, Etit 38) and the old cultivar Cappelli were also included in Q3, except for Haurani which was only clustered in Q3 when using the Ward clustering method. A gradient in the contribution of CIMMYT germplasm from Q5, passing through Q2 and finally to Q1 was shown from the three sub-populations with a major influence of the CGIAR durum wheat breeding programs. The WANA region germplasm, with greater influence or derived from ICARDA, was mostly represented by Q2 and Q1. In general, population structure analysis corroborates the previous pedigree information and the a priori relationships between parental lines with derivative lines and between sister lines.

\section{Conclusions}

The development of national breeding programs of durum wheat in Argentina began with the introduction of European germplasm, local breeding and subsequent incorporation of CIMMYT germplasm during the green revolution era. Three main national breeding programs have been permanently maintained over the last 50 years. Nowadays, some international companies have recently established breeding programs or released introduced cultivars. The present study demonstrated that the breeding germplasm developed in Argentina is the result of an admixture from different genetic sources. An important highlight is that selection patterns and diversity structure were identified in the germplasm subgroups resulting from decades of locally adapted breeding. Rare alleles can be used as sources of variability and may provide favorable alternatives for facing future challenges. 
From a breeding approach, the selection of a strategy for increasing allelic richness based on adaptive potential in the segregating germplasm is essential under a climate change scenario. Recent international effort has resulted in dynamic platforms or initiatives for sharing genetic resources that guarantee free germplasm exchange and permit a continual widening of the genetic base in breeding. On the other hand, the study of LD indicated that selection pressure during breeding has impacted differently on chromosomes resulting in differences in the extension and level of LD and haplotypes. This should be considered at the time of applying marker assisted selection.

\section{Methods and materials}

\section{Plant material}

A durum wheat (Triticum turgidum L. ssp. durum Desf. Husn) collection composed of 197 worldwide accessions (landraces, cultivars and breeding lines), including 168 genotypes previously described by [14], was used for this study. This collection is mostly representative of the Argentinian breeding programs (85), but also includes accessions from Italy (33), Chile (26), France (22), WANA (17), CIMMYT (10) and the USA (4) (Additional file 1: Table S1a). Both the Italian and Argentinian accessions were classified as 'traditional' or ' modern' (before and after 1985) based on previous results which detected an association of origins according the breeding period [14].

\section{SNP genotyping and data filtering}

DNA from each accession was extracted from fresh leaves of 10-day-old seedlings using a modified CTAB method, as described in [87]. The durum wheat collection was genotyped using the $35 \mathrm{~K}$ Axiom Wheat Breeder's Genotyping Array from Affymetrix [33] at TraitGenetics (Gatersleben, Germany) and CCT CONICET La Plata (Argentina). The SNP matrix was filtered, discarding the monomorphic markers, SNPs with $>10 \%$ of missing data and SNP with $>10 \%$ of heterozygosity. Markers with minor allele frequency $(\mathrm{MAF})<0.05$ were analyzed separately to study the diversity due to LF SNPS. The SNPs classified as polymorphic high resolution (Poly High-resolution) and off-target variant (OTV) having good cluster resolution were considered, following the recommendations for polyploid species of Axiom ${ }^{\bullet}$ Genotyping Solution Data Analysis Guide (http://www.affymetrix.com/). The OTV SNPs were analyzed with the OTV-caller function before use.

\section{Distribution and physical positions of polymorphic SNPs in the durum wheat genome}

The physical positions of the SNPs were obtained by BLASTN [88] of each SNP sequence on the durum wheat reference genome assembly (Svevo CV) (https://
wheat.pw.usda.gov/GG3/node/759), with a threshold of $95 \%$ for identity and coverage. Additional information of the SNP positions were obtained from nulli-tetrasomic lines (https://www.cerealsdb.uk.net), BLASTN results on bread wheat (http://plants.ensembl.org/Triticum aestivum/Info/Index), wild Emmer wheat genomes (https://wewseq.wixsite.com/consortium) and genetic positions on published linkage maps [33, 89, 90], especially if the SNPs showed multiple hits (homeologous or interchromosomic duplication). The SNPs positioned on the Svevo genome assembly were used to identify polymorphisms in annotated genes (http://plants.ensembl. org/Triticum_turgidum/Info/Index).

\section{Genetic diversity}

Basic genetic statistics were calculated using the GenAlex v6.5 software $[91,92]$ to describe genetic diversity including the percentage of polymorphic loci (\%PL), observed heterozygosity $(\mathrm{Ho})$, Nei's gene diversity (PIC= $\mathrm{He}=$ expected heterozygosity) $[93,94]$ and Shannon's information index $(I)$ [95]. The fixation index (Fst $=(\mathrm{Ht}-$ $\mathrm{Hs} / \mathrm{Ht}$ ) or genetic differentiation in populations index [96] was calculated between sub-populations detected by Discriminant Analysis of Principal Components (DAPC).

Polymorphic SNP markers that passed quality controls but showed an MAF $<0.05$ (LF), commonly called "rare alleles", were used to identify subgroups in the collection that could be considered as a reservoir of genetic diversity. These rare alleles are referred to as private alleles (PA) when only found in a single subgroup of a broader collection. Predefined groups according the country/region of origin (Argentinian traditional [ART], Argentinian modern [ARM], Chile [CHI], CIMMYT (México) [CIM], France [FRA], Italian traditional [ITT], Italian modern [ITM], United States [USA], West Asia/North Africa region [WANA]), the sub-populations from structure results and the ranges of periods of bred/released (1915-1959, 1960-1969, 1970-1979, 1980-1989, 19901999, 2000-2009, 2010-2020) were considered as subgroups for testing genetic differences.

\section{LD estimation and LD decay}

Linkage disequilibrium (LD) was calculated in the TASS EL 5.0 software [97] considering only SNPs with an MAF $>0.05$ to avoid a bias effect of the LF SNPs on LD [98]. LD was measured as the allele frequency correlation $\left(r^{2}\right)$ for all pairwise SNP comparison in each chromosome and subsequently the chromosome and genome specific mean values were estimated. Interchromosomic LD (unlinked loci) was estimated over the whole genome. The LD decay was determined by plotting the $r^{2}$ values against the genetic distance of loci pairs $(\mathrm{Mb})$ for each chromosome and a trend line describing the LD decay was calculated by locally-weighted 
polynomial regression (LOESS) in R (http://www.rproject.org). The 95th percentile of the distribution of square root transformed inter-chromosomal LD values $\left(r^{2}\right)$ [99] was estimated as the critical threshold below which the LD could be considered as being caused by physical linkage. The intersection point between the LD curve and the $r^{2}$ threshold determined the LD decay value for each chromosome.

\section{Population structure}

To assess the population structure, the SNPs were selected by considering inter-marker distances greater than $1 \mathrm{Mb}$ and MAF $>0.3$ to select informative and well distributed markers according to the recommendations of [86]. The population structure was explored by the Discriminant Analysis of Principal Components (DAPC) method implemented in the R package "adegenet" v2.0.1 [100] in R studio V 1.3.1056 ( $\mathrm{R}$ Development Core Team, 2011). The number of PC retained was selected by the cross-validation method using the xvalDapc function. The most probable $\mathrm{K}$ was declared, based on the lowest Bayesian Information Criterion (BIC) value following the [10] criteria. In addition, population structure was analyzed using the STRUCTURE v2.3.4 software (http://pritch.bsd.uchicago.edu/structure.html), selecting the admixture as the ancestry model and the correlated allele frequencies option [101]. Parameters were set at 100,000 burning periods and 100,000 Markov Chain Monte Carlo (MCMC) replicates using 5 independent runs for each $\mathrm{K}$ (1 to 10). No prior information was provided. The Evanno test [102] was used to identify the true number of sub-populations (K) implemented in the STRUCTURE HARVESTER website [103]. STRUCT URE results were plotted using the Pophelper 2.3.0 R library [104]. Furthermore, the Ward clustering baseddistance method was used to assess the genetic relationships between the accessions, based on a dissimilarity index calculated from the simple matching coefficient in DARwin v6.0 software [105]. The Ward dendrogram was drawn in the FigTree v1.4.3 software (http://tree.bio. ed.ac.uk/software/figtree/).

\footnotetext{
Abbreviations

CIMMYT: Centro Internacional de Mejoramiento de Maíz Y Trigo; CARDA: International Center for Agricultural Research In the Dry Areas; INIA: Instituto de Investigaciones Agropecuarias; CCT: Centro Científico Tecnológico; INTA: Instituto Nacional de Tecnología Agropecuaria; ACA: Asociación de Cooperativas Argentinas; LD: Linkage Disequilibrium; SNPs: Single Nucleotide Polymorphisms; KASP: Kompetitive Allele Specific PCR; MAF: Minor Allele Frequency; HF: High Frequency; LF: Low Frequency; PA: Private Alleles; LOESS: Locally-weighted polynomial regression; DAPC: Discriminant Analysis of Principal Components; AMOVA: Analysis of Molecular Variance; CGIAR: Consultative Group on International Agricultural Research; CTAB: Cetyl Trimethyl Ammonium Bromide; BIC: Bayesian Information Criterion; PCoA: Principal Coordinate Analysis
}

\section{Supplementary Information}

The online version contains supplementary material available at https://doi. org/10.1186/s12864-021-07519-z.

\section{Additional file 1. \\ Additional file 2. \\ Additional file 3. \\ Additional file 4. \\ Additional file 5 . \\ Additional file 6 . \\ Additional file 7. \\ Additional file 8. \\ Additional file 9. \\ Additional file 10.}

\section{Acknowledgments}

Thanks are due to all seed donors for providing us with the germplasm to build the collection analyzed in this study. In memory of Ing. Agr. (Professor) Rubén Miranda for his great support to our research activities, contributing with his knowledge and experience.

\section{Authors' contributions}

PFR and VE: conceived and designed the study; PFR: collected the entries, made seed purification and ensemble the collection; PFR, AOL: extracted the DNA of the collection and did structure and diversity analyses; SD, VE, PFR, CSP: obtained the genotyping; PFR, CG: performed the bioinformatics analyses on the genome; PFR: drafted the original manuscript; PFR, ALA, VE, SD, CSP, AOL: valorized the results, revised and re-wrote the manuscript. The authors read and approved the final manuscript.

\section{Funding}

This research has received financial assistance from CONICET, CERZOS - CCT CONICET Bahía Blanca, Universidad Nacional del Sur/ ME (NUTRIPASTA PCESU9-UNS993), ANPCYT: PICT 2015-1401. We also acknowledge the support of H2020-MSCA-RISE-2015 project ExpoSEED (grant no. 691109) and CGIAR Research Program WHEAT.

\section{Availability of data and materials}

Plant material and raw data are available upon request to the first author. Annotated genes are public available in http://plants.ensembl.org/Triticum_ turgidum/Info/Index. Phylogenetic tree, dissimilarity matrix and dataset to obtain them are available in http://purl.org/phylo/treebase/phylows/study/ TB2:S27474

\section{Declarations}

\section{Ethics approval and consent to participate}

The plant material was provided by the donors detailed in Table S1a, under the supervision of Dr. Pablo Roncallo. Research experiments follow all the statements signed by Argentina under the International Convention for the Protection of new varieties of plants (UPOV, 1991, Art 15.1) and the Argentinian national law $\mathrm{N}^{\circ}$ 20.247. No permissions to develop field experiment or research activities in durum wheat were necessary used in this study.

\section{Consent for publication}

Not applicable.

\section{Competing interests}

The authors declare that they have no competing interests.

\section{Author details}

'Centro de Recursos Naturales Renovables de la Zona Semiárida (CERZOS) Departamento de Agronomía, Universidad Nacional del Sur (UNS)-CONICET, Bahía Blanca, Argentina. ${ }^{2}$ CEl Barrow, Instituto Nacional de Tecnología Agropecuaria (INTA), Tres Arroyos, Buenos Aires, Argentina. International 
Maize and Wheat Improvement Center (CIMMYT), El Batán, Edo. de México, Mexico.

Received: 6 December 2020 Accepted: 2 March 2021

Published online: 05 April 2021

\section{References}

1. Bassi FM, Sanchez-Garcia M. Adaptation and stability analysis of ICARDA durum wheat elites across 18 countries. Crop Sci. 2017;57(5):2419-30. https://doi.org/10.2135/cropsci2016.11.0916.

2. Ranieri R. Geography of the durum wheat crop. Pastaria Int. 2015;6:24-36.

3. Salamini F, Özkan H, Brandolini A, Schafer-Pregl R, William M. Genetics and geography of wild cereal domestication in the near east. Nat Rev Genet. 2002;3(6):429-41. https://doi.org/10.1038/nrg817.

4. Sall AT, Chiari T, Legesse W, Seid-Ahmed K, Ortiz R, van Ginkel M, et al. Durum Wheat (Triticum durum Desf.): Origin, Cultivation and Potential Expansion in Sub-Saharan Africa. Agronomy 2019;9:263. https://doi.org/10.33 90/agronomy9050263.

5. Matsuo RR. Durum wheat: its unique pasta-making properties. In: Bushuk W, Rasper VF, editors. Wheat: production, properties and quality. Boston: Springer; 1994. p. 169-78. https://doi.org/10.1007/978-1-4615-2672-8_12.

6. García O. Inicio Del Cultivo De Trigo En La Argentina. In: Programa Nacional de Calidad de Trigo: In, Subsecretaría de Políticas Agropecuarias y Alimentos, Dirección Nacional de Mercados; 2004. https://www.magyp.gob.ar/new/0-0/progra mas/dma/publicaciones/calidad_de_trigo/inicio.php. Accessed 5 Sept 2020.

7. Byerlee D. Impact of durum wheat breeding in developing countries: a dilemma for the future. In: Rajaram S, Saari EE, Hettel GP, editors. Durum Wheats: challenges and opportunities. Mexico: CIMMYT; 1992. p. 28-43. ISBN: 968-6127-77-1.

8. UIFRA. Pastas secas, estadísticas sectoriales. Unión de industriales fideeros de la República Argentina. 2020. https://uifra.org.ar/wp-content/uploads/202 0/04/dossier2020v2.pdf. Accessed 8 Sept 2020.

9. Maccaferri M, Sanguineti MC, Natoli V, Araus Ortega JL, Salem MB, Bort J, et al. A panel of elite accessions of durum wheat (Triticum durum Desf.) suitable for association mapping studies. Plant Genet Res. 2006;4(1):79-85. https://doi.org/10.1079/PGR2006117.

10. Laidò G, Mangini G, Taranto F, Gadaleta A, Blanco A, Cattivelli L, et al. Genetic diversity and population structure of tetraploid wheats (Triticum turgidum L.) Estimated by SSR, DArT and Pedigree Data. PLoS ONE. 2013; 8(6):e67280. https://doi.org/10.1371/journal.pone.0067280.

11. Soriano JM, Villegas D, Aranzana MJ, García del Moral LF, Royo C. Genetic structure of modern durum wheat cultivars and mediterranean landraces matches with their agronomic performance. PLoS ONE. 2016;1 1(8):e0160983. https://doi.org/10.1371/journal.pone.0160983.

12. Kabbaj SA, Al-Abdallat A, Geleta M, Amri A, Filali-Maltouf A, Belkadi B, et al. Genetic diversity within a global panel of durum wheat (Triticum durum) landraces and modern germplasm reveals the history of alleles exchange. Front Plant Sci. 2017:18:1277. https://doi.org/10.3389/fpls.2017.01277.

13. N'Diaye A, Haile JK, Nilsen KT, Walkowiak S, Ruan Y, Singh AK, Clarke FR, Clarke JM, Pozniak CJ. Haplotype loci under selection in Canadian durum wheat Germplasm over 60 years of breeding: association with grain yield, quality traits, protein loss, and plant height. Front Plant Sci. 2018;9:1589. https://doi.org/10.3389/fpls.2018.01589.

14. Roncallo PF, Beaufort V, Larsen AO, Dreisigacker S, Echenique V. Genetic diversity and linkage disequilibrium using SNP (KASP) and AFLP markers in a worldwide durum wheat (Triticum turgidum L. var durum) collection. PLoS ONE. 2019;14(6):e0218562. https://doi.org/10.1371/journal.pone.0218562.

15. Wang S, Xu S, Chao S, Sun Q, Liu S, Xia G. A genome-wide association study of highly heritable agronomic traits in durum wheat. Front Plant Sci. 2019; 10:919. https://doi.org/10.3389/fpls.2019.00919.

16. Sansaloni C, Franco J, Santos B, Percival-Alwyn L, Singh S, Petroli C, Campos J, Dreher K, Payne T, Marshall D, Kilian B, Milne I, Raubach S, Shaw P, Stephen G, Carling J, Pierre CS, Burgueño J, Crosa J, Li HH, Guzman C, Kehel Z, Amri A, Kilian A, Wenzl P, Uauy C, Banziger M, Caccamo M, Pixley K. Diversity analysis of 80,000 wheat accessions reveals consequences and opportunities of selection footprints. Nat Commun. 2020;11(1):4572. https:// doi.org/10.1038/s41467-020-18404-w.

17. Taranto F, D'Agostino N, Rodriguez M, Pavan S, Minervini AP, Pecchioni N, Papa R, de Vita P. Whole genome scan reveals molecular signatures of divergence and selection related to important traits in durum wheat Germplasm. Front Genet. 2020;11:217. https://doi.org/10.3389/fgene.2020.00217.
18. Zhang H, Mittal N, Leamy $\amalg$, Barazani O, Song B-H. Back into the wild-apply untapped genetic diversity of wild relatives for crop improvement. Evol Appl. 2017;10(1):5-24. https://doi.org/10.1111/eva.12434.

19. Figliuolo $\mathrm{G}$, Mazzeo $\mathrm{M}$, Greco I. Temporal variation of diversity in Italian durum wheat germplasm. Genet Resour Crop Evol. 2007;54(3):615-26. https://doi.org/10.1007/s10722-006-0019-z.

20. Oliveira HR, Campana MG, Jones H, Hunt HV, Leigh F, Redhouse DI, Lister DL, Jones MK. Tetraploid wheat landraces in the Mediterranean Basin: taxonomy, Evolution and Genetic Diversity. PLoS ONE. 2012;7(5):e37063. https://doi.org/10.1371/journal.pone.0037063.

21. Sahri A, Chentoufi L, Arbaoui M, Ardisson M, Belqadi L, Birouk A, Roumet P, Muller $\mathrm{MH}$. Towards a comprehensive characterization of durum wheat landraces in Moroccan traditional agrosystems: analysing genetic diversity in the light of geography, farmers' taxonomy and tetraploid wheat domestication history. BMC Evol Biol. 2014;14(1):264. https://doi.org/10.1186/ s12862-014-0264-2.

22. Zarei Abbasabad E, Mohammadi S, Moghaddam M, Jalal KM. Analysis of genetic diversity, population structure and linkage disequilibrium in Iranian wheat landraces using SSR markers. Plant Genet Res. 2017;15(4):327-34. https://doi.org/10.1017/S1479262115000684.

23. Soriano JM, Malosetti M, Rosello M, Sorrells ME, Royo C. Dissecting the old Mediterranean durum wheat genetic architecture for phenology, biomass and yield formation by association mapping and QTL meta-analysis. PLoS One. 2017;12(5):e0178290. https://doi.org/10.1371/journal.pone.0178290.

24. Robbana C, Kehel Z, Ben Naceur M, Sansaloni C, Bassi F, Amri A. Genomewide genetic diversity and population structure of Tunisian durum wheat landraces based on DArTseq technology. Int J Mol Sci. 2019;20(6):1352. https://doi.org/10.3390/ijms20061352.

25. Peleg Z, Fahima T, Korol AB, Abbo S, Saranga Y. Genetic analysis of wheat domestication and evolution under domestication. J Exp Botany. 2011; 62(14):5051-61. https://doi.org/10.1093/jxb/err206.

26. Ivanizs L, Monostori I, Farkas A, Megyeri M, Mikó P, Türkösi E, Gaál E, LenykóThegze A, Szőke-Pázsi K, Szakács É, Darkó É, Kiss T, Kilian A, Molnár I. Unlocking the genetic diversity and population structure of a wild gene source of wheat, Aegilops biuncialis Vis., and its relationship with the heading time. Front Plant Sci. 2019;10:1531. https://doi.org/10.3389/fpls.201 9.01531.

27. Oliveira HR, Jacocks L, Czajkowska BI, Kennedy SL, Brown TA. Multiregional origins of the domesticated tetraploid wheats. PLoS One. 2020;15(1): e0227148. https://doi.org/10.1371/journal.pone.0227148.

28. Huang $X$, Han B. Natural variations and genome-wide association studies in crop plants. Annu Rev Plant Biol. 2014;65(1):531-51. https://doi.org/10.114 6/annurev-arplant-050213-035715.

29. Rasheed A, Hao Y, Xia X, Khan A, Xu Y, Varshney RK, He Z. Crop breeding chips and genotyping platforms: progress, challenges, and perspectives. Mol Plant. 2017;10(8):1047-64. https://doi.org/10.1016/j.molp.2017.06.008.

30. Cavanagh CR, Chao S, Wang S, Huang BE, Stephen S, Kianic S, et al. Genome-wide comparative diversity uncovers multiple targets of selection for improvement in hexaploid wheat landraces and cultivars. PNAS. 2013; 110(20):8057-62. https://doi.org/10.1073/pnas.1217133110.

31. Wang S, Wong D, Forrest $K$, Allen A, Chao S, Huang BE, Maccaferri M, Salvi S, Milner SG, Cattivelli L, Mastrangelo AM, Whan A, Stephen S, Barker G, Wieseke R, Plieske J, International Wheat Genome Sequencing Consortium, Lillemo M, Mather D, Appels R, Dolferus R, Brown-Guedira G, Korol A, Akhunova AR, Feuillet C, Salse J, Morgante M, Pozniak C, Luo MC, Dvorak J, Morell M, Dubcovsky J, Ganal M, Tuberosa R, Lawley C, Mikoulitch I, Cavanagh C, Edwards KJ, Hayden M, Akhunov E. Characterization of polyploid wheat genomic diversity using a high-density 90,000 single nucleotide polymorphism array. Plant Biotechnol J. 2014;12(6):787-96. https://doi.org/10.1111/pbi.12183.

32. Winfield MO, Allen AM, Burridge AJ, Barker GL, Benbow HR, Wilkinson PA, et al. High-density SNP genotyping array for hexaploid wheat and its secondary and tertiary gene pool. Plant Biotechnol J. 2016;14(5):1195-206. https://doi.org/10.1111/pbi.12485.

33. Allen AM, Winfield MO, Burridge AJ, Downie RC, Benbow HR, Barker GLA, Wilkinson PA, Coghill J, Waterfall C, Davassi A, Scopes G, Pirani A, Webster T, Brew F, Bloor C, Griffiths S, Bentley AR, Alda M, Jack P, Phillips AL, Edwards KJ. Characterization of a wheat breeders' Array suitable for high-throughput SNP genotyping of global accessions of hexaploid bread wheat (Triticum aestivum). Plant Biotechnol J. 2017;15(3):390-401. https://doi.org/10.1111/ pbi.12635. 
34. Cui F, Zhang N, Fan X-L, Zhang W, Zhao C-H, Yang L-J, et al. Utilization of a Wheat 660K SNP array-derived high-density genetic map for high-resolution mapping of a major QTL for kernel number. Sci Rep. 2017;7:3788. https:// doi.org/10.1038/s41598-017-04028-6.

35. Elshire RJ, Glaubitz JC, Sun Q, Poland JA, Kawamoto K, Buckler ES, Mitchell SE. A robust, simple genotyping-by-sequencing (GBS) approach for high diversity species. PLoS One. 2011;6(5):e19379. https://doi.org/10.1371/journal. pone.0019379.

36. Baloch FS, Alsaleh A, Shahid MQ, Çiftçi V, Sáenz de Miera L, Aasim M, et al. A whole genome dartseq and snp analysis for genetic diversity assessment in durum wheat from central fertile crescent. PLoS ONE. 2017;12(1): e0167821. https://doi.org/10.1371/journal.pone.0167821.

37. Avni R, Nave M, Barad O, Baruch K, Twardziok SO, Gundlach H, Hale I, Mascher M, Spannagl M, Wiebe K, Jordan KW, Golan G, Deek J, Ben-Zvi B, Ben-Zvi G, Himmelbach A, MacLachlan RP, Sharpe AG, Fritz A, Ben-David R, Budak H, Fahima T, Korol A, Faris JD, Hernandez A, Mikel MA, Levy AA, Steffenson B, Maccaferri M, Tuberosa R, Cattivelli L, Faccioli P, Ceriotti A Kashkush K, Pourkheirandish M, Komatsuda T, Eilam T, Sela H, Sharon A, Ohad N, Chamovitz DA, Mayer KFX, Stein N, Ronen G, Peleg Z, Pozniak CJ, Akhunov ED, Distelfeld A. Wild emmer genome architecture and diversity elucidate wheat evolution and domestication. Science. 2017;357(6346):93-7. https://doi.org/10.1126/science.aan0032

38. The International Wheat Genome Sequencing Consortium (IWGSC), Appels R, Eversole K, Stein N, Feuillet C, Keller B, et al. Shifting the limits in wheat research and breeding using a fully annotated reference genome. Science. 2018;361:eaar7191. https://doi.org/10.1126/science.aar7191.

39. Maccaferri M, Harris NS, Twardziok SO, Pasam RK, Gundlach H, Spannagl M, Ormanbekova D, Lux T, Prade VM, Milner SG, Himmelbach A, Mascher M, Bagnaresi P, Faccioli P, Cozzi P, Lauria M, Lazzari B, Stella A, Manconi A, Gnocchi M, Moscatelli M, Avni R, Deek J, Biyiklioglu S, Frascaroli E, Corneti S, Salvi S, Sonnante G, Desiderio F, Marè C, Crosatti C, Mica E, Özkan H, Kilian B, de Vita P, Marone D, Joukhadar R, Mazzucotelli E, Nigro D, Gadaleta A, Chao S, Faris JD, Melo ATO, Pumphrey M, Pecchioni N, Milanesi L, Wiebe K, Ens J, MacLachlan RP, Clarke JM, Sharpe AG, Koh CS, Liang KYH, Taylor GJ, Knox R, Budak H, Mastrangelo AM, Xu SS, Stein N, Hale I, Distelfeld A, Hayden MJ, Tuberosa R, Walkowiak S, Mayer KFX, Ceriotti A, Pozniak CJ, Cattivelli L. Durum wheat genome highlights past domestication signatures and future improvement targets. Nat Genet. 2019;51(5):885-95. https://doi. org/10.1038/s41588-019-0381-3.

40. Flint-Garcia SA, Thornsberry JM, Buckler ES. Structure of linkage disequilibrium in plants. Annu Rev Plant Biol. 2003;54(1):357-74. https://doi. org/10.1146/annurev.arplant.54.031902.134907.

41. Maccaferri M, Sanguineti MC, Noli E, Tuberosa R. Population structure and long-range linkage disequilibrium in a durum wheat elite collection. Mol Breed. 2005;15(3):271-89. https://doi.org/10.1007/s11032-004-7012-z.

42. Laidò G, Marone D, Russo MA, Colecchia SA, Mastrangelo AM, De Vita P, et al. Linkage Disequilibrium and Genome-Wide Association Mapping in Tetraploid Wheat (Triticum turgidum L.). PLoS ONE. 2014;9(4):e95211. https:// doi.org/10.1371/journal.pone.0095211.

43. Mengistu DK, Kidane YG, Catellani M, Frascaroli E, Fadda C, Pè ME, Dell'Acqua M. High-density molecular characterization and association mapping in Ethiopian durum wheat landraces reveals high diversity and potential for wheat breeding. Plant Biotechnol J. 2016;14(9):1800-12. https:// doi.org/10.1111/pbi.12538.

44. Hill WG, Weir BS. Variances and covariances of squared linkage disequilibria in finite populations. Theor Popul Biol. 1988;33(1):54-78. https://doi.org/10.1 016/0040-5809(88)90004-4.

45. Yan J, Shah T, Warburton ML, Buckler ES, McMullen MD, Crouch J. Genetic characterization and linkage disequilibrium estimation of a global maize collection using SNP markers. PLoS One. 2009;4(12):e8451. https://doi.org/1 0.1371/journal.pone.0008451.

46. Krattinger SG, Keller B. Molecular genetics and evolution of disease resistance in cereals. New Phytol. 2016;212(2):320-32. https:/doi.org/10.1111/nph.14097.

47. Lopes MS, El-Basyoni I, Baenziger S, Singh S, Royo C, Ozbek K, et al. Exploiting genetic diversity from landraces in wheat breeding for adaptation to climate change. J Exp Bot. 2015;66(12):3477-86. https://doi. org/10.1093/jxb/erv122.

48. Rufo R, Alvaro F, Royo C, Soriano JM. From landraces to improved cultivars: assessment of genetic diversity and population structure of Mediterranean wheat using SNP markers. PLoS One. 2019;14(7):e0219867. https://doi.org/1 0.1371/journal.pone.0219867.
49. Payne PI, Holt LM, Lawrence GJ, Law CN. The genetics of gliadin and glutenin, the major storage proteins of the wheat endosperm. Plant Foods Hum Nutr. 1982;31(3):229-41. https://doi.org/10.1007/BF01108632.

50. Qin X, Zhang W, Dubcovsky J, Tian L. Cloning and comparative analysis of carotenoid $\beta$-hydroxylase genes provides new insights into carotenoid metabolism in tetraploid (Triticum turgidum ssp. durum) and hexaploid (Triticum aestivum) wheat grains. Plant Mol Biol. 2012;80(6):631-46. https:// doi.org/10.1007/s11103-012-9972-4.

51. Li Z, Mouille G, Kosar-Hashemi B, Rahman S, Clarke B, Gale KR, Appels R, Morell MK. The structure and expression of the wheat starch synthase III gene. Motifs in the expressed gene define the lineage of the starch synthase III gene family. Plant Physiol. 2000;123(2):613-24. https://doi.org/1 0.1104/pp.123.2.613.

52. Menga $V$, Trono $D$. The molecular and functional characterization of the durum wheat Lipoxygenase TdLOX2 suggests its role in hyperosmotic stress response. Plants. 2020;9(9):1233. https://doi.org/10.3390/plants9091233.

53. Ren J, Sun D, Chen L, You FM, Wang J, Peng Y, Nevo E, Sun D, Luo MC, Peng J. Polymorphism markers in a worldwide Germplasm collection of durum wheat. Int J Mol Sci. 2013;14(4):7061-88. https://doi.org/10.3390/ ijms14047061.

54. Caballero A, Rodriguez-Ramilo S, Avila V, Fernandez J. Management of genetic diversity of subdivided populations in conservation programmes. Conserv Genet. 2010;11(2):409-19. https://doi.org/10.1007/s10592-009-0020-0.

55. Slatkin M. Rare alleles as indicators of gene flow. Evolution. 1985;39(1):53-65. https://doi.org/10.1111/j.1558-5646.1985.tb04079.x.

56. López-Cortegano E, Pouso R, Labrador A, Pérez-Figueroa A, Fernández J, Caballero A. Optimal Management of Genetic Diversity in subdivided populations. Front Genet. 2019;10:843. https://doi.org/10.3389/fgene.2019. 00843.

57. Caballero A, García-Dorado A. Allelic diversity and its implications for the rate of adaptation. Genetics. 2013;195(4):1373-84. https://doi.org/10.1534/ genetics.113.158410.

58. Bassi FM, Nachit MM. Genetic gain for yield and allelic diversity over 35 years of durum wheat breeding at ICARDA. Crop Breed Genet Genom. 2019;1:e190004. https://doi.org/10.20900/cbgg20190004.

59. Crossa J. Methodologies for estimating the sample size required for genetic conservation of outbreeding crops. Theor Appl Genet. 1989;77(2):153-61. https://doi.org/10.1007/BF00266180.

60. Avni R, Oren L, Shabtay G, Assili S, Pozniak C, Hale I, Ben-David R, Peleg Z, Distelfeld A. Genome based meta-QTL analysis of grain weight in Tetraploid wheat identifies rare alleles of GRF4 associated with larger grains. Genes (Basel). 2019;9(12):636. https://doi.org/10.3390/genes9120636.

61. Hu J, Wang Y, Fang Y, Zeng L, Xu J, Yu H, Shi Z, Pan J, Zhang D, Kang S, Zhu L, Dong G, Guo L, Zeng D, Zhang G, Xie L, Xiong G, Li J, Qian Q. A rare allele of GS2 enhances grain size and grain yield in Rice. Mol Plant. 2015; 8(10):1455-65. https://doi.org/10.1016/j.molp.2015.07.002.

62. Balfourier F, Bouchet S, Robert S, De Oliveira R, Rimbert H, Kitt J, et al. Worldwide phylogeography and history of wheat genetic diversity. Sci Adv. 2019;5:eaav0536. https://doi.org/10.1126/sciadv.aav0536.

63. Falconer DS, Mackay TFC. Introduction to quantitative genetics. 4th ed. Harlow: Longmans Green; 1996.

64. Gaut BS, Long AD. The lowdown on linkage disequilibrium. Plant Cell. 2003; 15(7):1502-6. https://doi.org/10.1105/tpc.150730.

65. Roselló M, Royo C, Sanchez-Garcia M, Soriano MJ. Genetic dissection of the seminal root system architecture in mediterranean durum wheat landraces by genome-wide association study. Agronomy. 2019;9:364. https://doi.org/1 0.3390/agronomy9070364.

66. Afzal F, Li H, Gul A, Subhani A, Ali A, Mujeeb-Kazi A, Ogbonnaya F, Trethowan R, Xia X, He Z, Rasheed A. Genome-wide analyses reveal footprints of divergent selection and drought adaptive traits in synthetic-derived Wheats. G3. 2019; 9(6):1957-73. https://doi.org/10.1534/g3.119.400010.

67. N'Diaye A, Haile JK, Cory AT, Clarke FR, Clarke JM, Knox RE, et al. Single marker and haplotype-based association analysis of semolina and pasta colour in elite durum wheat breeding lines using a high-density consensus map. PLoS One. 2017;12(1):e0170941. https://doi.org/10.1371/journal.pone.0170941.

68. Bassi FM, Brahmi H, Sabraoui A, Amri A, Nsarellah N, Nachit MM, al-Abdallat A, Chen MS, Lazraq A, el Bouhssini M. Genetic identification of loci for hessian fly resistance in durum wheat. Mol Breed. 2019;39(2):24. https://doi. org/10.1007/s11032-019-0927-1.

69. Vos PG, Paulo MJ, Voorrips RE, Visser RGF, van Eck HJ, van Eeuwijk FA. Evaluation of LD decay and various LD-decay estimators in simulated and 
SNP-array data of tetraploid potato. Theor Appl Genet. 2017;130(1):123-35. https://doi.org/10.1007/s00122-016-2798-8.

70. He S, Reif JC, Korzun V, Bothe R, Ebmeyer E, Jiang Y. Genome-wide mapping and prediction suggests presence of local epistasis in a vast elite winter wheat populations adapted to Central Europe. Theor Appl Genet. 2017;130(4):635-47. https://doi.org/10.1007/s00122-016-2840-x.

71. Slatkin M. Linkage disequilibrium -understanding the evolutionary past and mapping the medical future. Nat Rev Genet. 2008;9(6):477-85. https:/doi. org/10.1038/nrg2361.

72. Joukhadar R, Daetwyler HD, Gendall AR, Hayden MJ. Artificial selection causes significant linkage disequilibrium among multiple unlinked genes in Australian wheat. Evol Appl. 2019;12(8):1610-25. https://doi.org/10.1111/ eva.12807.

73. Maccaferri M, Cane MA, Sanguineti MC, Salvi S, Colalongo MC, Massi A, et al. A consensus framework map of durum wheat (Triticum durum Desf.) suitable for linkage disequilibrium analysis and genome-wide association mapping. BMC Genomics. 2014;15(1):873. http://www.biomedcentral.com/14 71-2164/15/873. https://doi.org/10.1186/1471-2164-15-873.

74. Wilhelm EP, Howells RM, Al-Kaff N, Jia J, Baker C, Leverington-Waite MA, et al. Genetic characterization and mapping of the Rht-1 homoeologs and flanking sequences in wheat. Theor Appl Genet. 2013;126(5):1321-36. https://doi.org/10.1007/s00122-013-2055-3.

75. Wilhelm EP, Turner AS, Laurie DA. Photoperiod insensitive Ppd-A1a mutations in tetraploid wheat (Triticum durum Desf.). Theor Appl Genet. 2009;1 18(2):285-94. https://doi.org/10.1007/s00122-008-0898-9.

76. Jackson EA, Holt LM, Payne PI. Glu-B2, a storage protein locus controlling the D group of LMW glutenin subunits in bread wheat (Triticum aestivum). Genet Res. 1985;46:17. https://doi.org/10.1017/S0016672300022412.

77. Joppa LR, Khan K, Williams ND. Chromosomal location of genes for gliadin polypeptides in durum wheat Triticum turgidum. Theor Appl Genet. 1983; 64(4):289-93. https://doi.org/10.1007/BF00274164.

78. Su ZQ, Hao CY, Wang LF, Dong YC, Zhang XY. Identification and development of a functional marker of TaGW2 associated with grain weight in bread wheat (Triticum aestivum L.). Theor Appl Genet. 2011;122:211-23. https://doi.org/10.1007/s00122-010-1437-z.

79. Khalid M, Afzal F, Gul A, Amir R, Subhani A, Ahmed Z, Mahmood Z, Xia X, Rasheed A, He Z. Molecular characterization of 87 functional genes in wheat diversity panel and their association with phenotypes under well-watered and water-limited conditions. Front Plant Sci. 2019;10:717. https://doi.org/1 0.3389/fpls.2019.00717.

80. Chao S, Dubcovsky J, Dvorak J, Luo M-C, Baenziger SP, Matnyazov R, Clark DR, Talbert LE, Anderson JA, Dreisigacker S, Glover K, Chen J, Campbell K, Bruckner PL, Rudd JC, Haley S, Carver BF, Perry S, Sorrells ME, Akhunov ED. Population- and genome-specific patterns of linkage disequilibrium and SNP variation in spring and winter wheat (Triticum aestivum L.). BMC Genomics. 2010;11(1):727. https://doi.org/10.1186/1471-2164-11-727.

81. Hu X, Ren J, Ren X, Huang S, Sabiel SA, Luo M, et al. Association of Agronomic Traits with SNP Markers in Durum Wheat (Triticum turgidum L. durum (Desf.)). PLoS ONE. 2015;10(6):e0130854. https://doi.org/10.1371/ journal.pone.0130854.

82. Pressoir $\mathrm{G}$, Berthaud J. Patterns of population structure in maize landraces from the central valleys of Oaxaca in Mexico. Heredity. 2004;92(2):88-94. https://doi.org/10.1038/sj.hdy.6800387.

83. He T, Lamont BB, Krauss SL, Enright NJ. Genetic connectivity and interpopulation seed dispersal of Banksia hookeriana at the landscape scale. Ann Bot. 2010;106(3):457-66. https://doi.org/10.1093/aob/mcq140.

84. Samberg LH, Fishman L, Allendorf FW. Population genetic structure in a social landscape: barley in a traditional Ethiopian agricultural system. Evol Appl. 2013;6(8):1133-45. https://doi.org/10.1111/eva.12091.

85. Pautasso M, Aistara G, Barnaud A, Caillon S, Clouvel P, Coomes OT, et al. Seed exchange networks for agrobiodiversity conservation. A review. Agron Sustain Dev. 2013;33(1). https://doi.org/10.1007/s13593-012-0089-6.

86. Linck E, Battey JC. Minor allele frequency thresholds strongly affect population structure inference with genomic data sets. Mol Ecol Resour. 2019;19(3):639-47. https://doi.org/10.1111/1755-0998.12995.

87. Dreisigacker S, Sehgal D, Reyes Jaimez AE, Luna Garrido B, Muñoz ZS, et al. CIMMYT Wheat Molecular Genetics: Laboratory Protocols and Applications to Wheat Breeding. Mexico: CIMMYT; 2016.

88. Altschul SF, Gish W, Miller W, Myers EW, Lipman DJ. Basic local alignment search tool. J Mol Biol. 1990;215(3):403-10. https://doi.org/10.1016/S0022-2 836(05)80360-2.
89. Avni R, Nave M, Eilam T, Sela H, Alekperov C, Peleg Z, Dvorak J, Korol A, Distelfeld A. Ultra-dense genetic map of durum wheat $\mathrm{x}$ wild emmer wheat developed using the 90K iSelect SNP genotyping assay. Mol Breed. 2014; 34(4):1549-62. https://doi.org/10.1007/s11032-014-0176-2.

90. Maccaferri M, Ricci A, Salvi S, Milner SG, Noli E, Martelli PL, Casadio R, Akhunov E, Scalabrin S, Vendramin V, Ammar K, Blanco A, Desiderio F, Distelfeld A, Dubcovsky J, Fahima T, Faris J, Korol A, Massi A, Mastrangelo AM, Morgante M, Pozniak C, N'Diaye A, Xu S, Tuberosa R. A high-density, SNP-based consensus map of tetraploid wheat as a bridge to integrate durum and bread wheat genomics and breeding. Plant Biotechnol J. 2015; 13(5):648-63. https://doi.org/10.1111/pbi.12288.

91. Peakall R, Smouse PE. GenAlEx 6.5: genetic analysis in excel. Population genetic software for teaching and research —an update. Bioinformatics. 2012;28(19):2537-9. https://doi.org/10.1093/bioinformatics/bts460.

92. Peakall R, Smouse PE. GENALEX 6: genetic analysis in excel. Population genetic software for teaching and research. Mol Ecol. 2006;6(1):288-95. https://doi.org/10.1111/j.1471-8286.2005.01155.x.

93. Nei M. Analysis of gene diversity in subdivided populations. Proc Natl Acad Sci. 1973;70(12):3321-3. https://doi.org/10.1073/pnas.70.12.3321.

94. Anderson JA, Churchill GA, Autrique JE, Tanksley SD, Sorrells ME. Optimizing parental selection for genetic linkage maps. Genome. 1993;36(1):181-6. https://doi.org/10.1139/g93-024.

95. Lewontin RC. The apportionment of human diversity. Evol Biol. 1973;6:38198. https://doi.org/10.1007/978-1-4684-9063-3_14.

96. Wright S. The genetical structure of populations. Ann Eugenics. 1951;15(1): 323-54. https://doi.org/10.1111/j.1469-1809.1949.tb02451.x.

97. Bradbury PJ, Zhang Z, Kroon DE, Casstevens TM, Ramdoss Y, Buckler ES. TASSEL: software for association mapping of complex traits in diverse samples. Bioinformatics. 2007;23(19):2633-5. https://doi.org/10.1093/ bioinformatics/btm308.

98. Weir BS. Genetic data analysis II: methods for discrete population genetic data. Sunderland: Sinauer Associates Inc.; 1996.

99. Breseghello F, Sorrells ME. Association mapping of kernel size and milling quality in wheat (Triticum aestivum L.) cultivars. Genetics. 2006;172(2):116577. https://doi.org/10.1534/genetics.105.044586.

100. Jombart T, Devillard S, Balloux F. Discriminant analysis of principal components: a new method for the analysis of genetically structured populations. BMC Genet. 2010;11(1):94. https://doi.org/10.1186/1471-21 56-11-94.

101. Falush D, Stephens M, Pritchard JK. Inference of population structure using multilocus genotype data, linked loci and correlated allele frequencies. Genetics. 2003;164:1567-87 PMID: 12930761; PMCID: PMC1462648.

102. Evanno G, Regnaut S, Goudet J. Detecting the number of clusters of individuals using the software STRUCTURE: a simulation study. Mol Ecol. 2005;14(8):2611-20. https://doi.org/10.1111/j.1365-294X.2005.02553.x.

103. Earl DA, Von Holdt BM. STRUCTURE HARVESTER: a website and program for visualizing STRUCTURE output and implementing the Evanno method. Conserv Genet Resour. 2012;4(2):359-61. https://doi.org/10.1007/s12686-0119548-7.

104. Francis RM. POPHELPER: an R package and web app to analyse and visualize population structure. Mol Ecol Resour. 2017;17(1):27-32. https://doi.org/1 0.1111/1755-0998.12509.

105. Perrier $X$, Jacquemoud-Collet JP. DARwin software. 2006. http://darwin.cirad.fr/

\section{Publisher's Note}

Springer Nature remains neutral with regard to jurisdictional claims in published maps and institutional affiliations.

\section{Ready to submit your research? Choose BMC and benefit from:}

- fast, convenient online submission

- thorough peer review by experienced researchers in your field

- rapid publication on acceptance

- support for research data, including large and complex data types

- gold Open Access which fosters wider collaboration and increased citations

- maximum visibility for your research: over $100 \mathrm{M}$ website views per year

At BMC, research is always in progress.

Learn more biomedcentral.com/submissions 